\title{
The Concept, Principle, Law and Developmental Practice of Environmental Democracy towards Sustainable Development in Resources-rich Communities of Developing Countries: Focus on Nigeria's Oil Producing Delta Region
}

\author{
Edward T. Bristol-Alagbariya* \\ Associate Dean \& Senior Multidisciplinary Lecturer, Faculty of Law, University of Port Harcourt, \\ NIGERIA; Affiliate Visiting Fellow, University of Aberdeen, UNITED KINGDOM; and Visiting Research \\ Fellow, Centre for Energy, Petroleum \& Mineral Law and Policy (CEPMLP), Graduate School of Natural \\ Resources Law, Policy \& Management, University of Dundee, Scotland, UNITED KINGDOM
}

\begin{abstract}
This study explains that environmental democracy is an aspect of Public Participation (PP), of which community participation is also an aspect. On this note, the study examines PP, simply known as 'participation', as a concept, principle, as well as a developmental practice, backed by law, in countries around the globe. It demonstrates that PP, particularly, environmental democracy, generates good, sound and long-lasting decisions. It establishes that such decisions protect public interest, enhance social equity, improve the quality of the environment, and promote environmental justice, good environmental governance (GEG), overall good public sector governance (GG) as well as sustainable development (SD), in the course of major natural resources (MNRs) extractive industrial operations (EIOs). EIOs, such as oil and gas, and other mining and mineral resources EIOs in resources-rich communities of developing countries, are exemplified by petroleum resources development operations (PRDOs) in the oil-rich Niger Delta region. Distinguished by its dominant PRDOs, the study features Nigeria as a typical example of a developing country plagued by the resource curse, and that the country is far from achieving SD, particularly sustainable petroleum resources development operations (SPRDOs) and sustainable community development (SCD) in its oil-rich Delta region. The study establishes that genuine environmental democracy, which is globally acknowledged and widely accepted, is that which is stipulated in Principle 10 of Rio Declaration on Environment and Development, 1992, elaborated in the Aarhus Convention, 1998, cemented in the UN Brisbane Declaration on Community Engagement, 2005, and being profoundly canvassed by the International Association for Impact Assessment (IAIA: the leading global network on environmental democracy in the realm of Impact Assessment [IA]) and the International Association for Public Participation (IAP2: the worldwide organisation exceptionally advancing and extending the practice of PP). The study recommends that the worldwide landmark degree of environmental democracy, which is regarded as genuine, should be practised in Nigeria to promote SPRDOs and SCD in the oil-rich communities of the Delta region, as well as stimulate greater human wellbeing, and environmentally-sound, ecologically-centred and socio-economically equitable SD in the country, towards the wellbeing of overall nature within the Planet Earth.

Keywords: Environmental Democracy, Public Participation (PP), Public Involvement Participation (PI), Community Involvement (CI), Major Natural Resources (MNRs) Extractive Industrial Operations (EIOs), Resource Curse, Sustainable Petroleum Resources Development Operations (SPRDOs), Sustainable Community Development (SCD), Good Environmental Governance (GEG) and Good Public Sector Governance (Good Governance $[\mathrm{GG}])$.
\end{abstract}

DOI: $10.7176 / \mathrm{JLPG} / 94-07$

Publication date: February $29^{\text {th }} 2020$

\section{Introduction}

It is important to state from onset that based on ethnic colouration and configuration of Nigeria and the analytical context of this study, the Niger Delta region, is considered in both narrow and broad perspectives. The narrow perspective presents the ethnographic, historic, geographic and ethnic minority Delta region, while the broad perspective presents the artificial and politically diluted oil producing Niger Delta region (which was created by the Niger Delta Development Commission [NDDC] Act). ${ }^{1}$ The former perspective shows the true ethnic minority Delta region of Nigeria, which is made up of the six states of the country (within Nigeria's South-South geopolitical zone) namely Rivers, Delta, Bayelsa, Akwa-Ibom, Edo and Cross-River states (including the oilproducing areas of Ondo state). Conversely, the latter perspective covers the artificial and politically diluted oil producing Niger Delta region, which is made up of the entire nine oil producing states of Nigeria, namely the

${ }^{1}$ Sections 2 (1) (b) and 4 of the Niger-Delta Development Commission (Establishment) Act, Act No 6. Laws of the Federation of Nigeria (LFN) 2000, Cap N86 LFN 2004; Niger Delta Development Commission (Establishment) Amendment Act, 2017; Niger Delta Development Commission (NDDC), Niger Delta Regional Development Master Plan (NDDC 2006), 49-50, 53-55, 60-67. 
seven other oil producing states mentioned above and two additional states: Abia and Imo). ${ }^{1}$

\section{The Concept, Principle, Law and Practice of Environmental Democracy}

Environmental democracy simply means public participation (PP) in environmental decision-making, which has three pillars, namely access to information on environmental matters, PP in environmental decision-making and access to justice in environmental matters. ${ }^{2}$ In the course of environmental democracy in the ongoing era of Sustainable Development (SD), engagement of citizens and citizen-groups is increasingly taking a centre stage in environmental decision-making processes, ranging from decision-making to decision-implementation processes, which are associated with developmental plans, policies and projects (including programmes [PPPs]), within local communities, cities, societies and countries around the world. ${ }^{3}$

As would be observed in the course of the examination and analysis of this study, PP evolved as a concept and principle, to become a developmental practice, which is backed by law. Participation is backed by relevant laws, regulations and regulatory practices in countries around the world. ${ }^{4}$

\section{The Increasing Public Awareness of and the Prevailing Nature of PP in the Ongoing Era of SD Considered as Participation Explosion and Principle 10 of Rio Declaration on Environment and Development, 1992}

Citizens and citizen-groups of global states, local communities and societies around the globe, are, in the ongoing era of SD, increasingly becoming aware of the need for and essence of PP as well as the prevailing nature and required degree of participation, particularly environmental democracy, in the course of executing developmental project proposals, which have the potential to adversely affect the environment and human wellbeing. ${ }^{5}$

PP, otherwise called PI, which environmental democracy constitutes an integral part and parcel of, may be defined or described as a popular democratic notion of lay citizens' involvement in local issues affecting the citizens. ${ }^{6}$ It connotes, denotes, implies and emphasises any of several mechanisms, techniques, processes and/or procedures, which is intentionally instituted to involve the lay public or their representatives in public/government administrative decision-making. PP, which may simply and precisely be called 'participation' is an allencompassing label used to describe the various forms by which individuals or groups may use to communicate their views on public issues in the context of the worldwide emerging participation opportunities. These include 'citizens' participation', 'citizens' involvement', 'stakeholders' engagement', 'indigenous peoples' rights', 'local community or town meetings', 'focus group meetings', 'local community rights', 'public hearings', 'public comments', 'stakeholders' advisory councils', 'stakeholders advisory committees', citizens' juries, citizens' mediation', 'NGO intervention', 'right to information', 'right to participation', 'right to decision-making', 'right to justice', 'right to environmental justice', 'right to environmental democracy', 'right to voting', 'decisional transfers', 'benefits sharing', and 'participation affected groups and organisations'. PP entails voting, demonstrating, petitioning, protesting, criticising, lobbying, and writing and speaking to the media, political leaders and governments, publishing newsletters, pamphlets, brochures and other documents, debating, campaigning, appearing and partaking in public hearings, and community empowerment, community development, and SD opportunities, as well as various other variants of citizens' involvement within the threshold of $\mathrm{PP}^{7}$ that cater for the concerns and interests of potentially affected citizens, citizen groups and their representatives.

\footnotetext{
${ }^{1}$ E. T. Bristol-Alagbariya, Participation in Petroleum Development: Towards Sustainable Community Development in the Niger Delta (Centre for Energy, Petroleum \& Mineral Law \& Policy [CEPMLP]/Dundee University Press [DUP] 2010) 29, 31, 35-36 and 43.

${ }^{2}$ Center for International Environmental Law (CIEL), 'Environmental Democracy' $<$ https://www.ciel.org/issue/environmental-democracyaccess-rights/> Accessed 7 February, 2020; R. Sidaway, Resolving Environmental Disputes from Conflicts to Consensus (Earthscan 2013).

${ }^{3}$ A. Wilkinson et al (eds), The Oxford Handbook of Participation in Organizations (Oxford University Press 2010); B. Cook and U. Kothari (eds), Participation: The New Tyranny? (Zed Books 2004); C. O. N. Moser, Community Participation in Urban Projects in the Third World (Progress in Planning S.) (Pergamon 1990); G. G. Holdar and O. Zakharchenko (eds), Citizen Participation Handbook: People's Voice Project International Centre for Policy Studies (iMedia 2002); M. Bamberger, Role of Community Participation in Development Planning and Project: Edi Policy Seminar Report (World Bank 1998); R. Russell and V. Rus (eds), International Handbook of Participation in Organizations: Ownership and Participation (Oxford University Press 1991).

${ }^{4}$ U. Etemire, Law and Practice of Public Participation in Environmental Matters: The Nigerian Example in Transnational Corporative Perspective (Routledge 2016); Section 14 (1) (c), Section 15 (4), Section 16 (1) (c), Section 16 (4) (c) and Section 39 of the 1999 Constitution of the Federal Republic of Nigeria (CFRN) (as amended); Freedom of Information Act, LFN 2011; Sections 14, 15, 16 and 39 of the 1999 CFRN (as amended) are captioned 'The Government and the People'; 'Political Objectives'; Economic Objectives', and 'Right to Freedom of Expression and the Press', respectively.

${ }^{5}$ M. Mulgan, People and Participation: How to Put Citizens at the Heart of Decision-making (Involve 2005); Homepage of Involve <https://www.involve.org.uk> Accessed 7 February, 2020; Principle 1, Rio Declaration on Environment and Development, 1992, which provides that human beings are at the centre of concerns for sustainable development. They are entitled to a healthy and productive life in harmony with nature; UNEP, Healthy Environment, Healthy People (UNEP 2016); J. F. Sachs, The Age of Sustainable Development (University of Columbia Press 2015)

${ }^{6}$ T. C. Beierle and J. Cayford, Democracy in Practice: Public Participation in Environmental Decisions (Resources for the Future 2002 ), 6.

${ }^{7}$ D. N. Zillman et al (eds), Human Rights in Natural Resources Development: Public Participation in Sustainable Development of Mining and Energy Resources (International Bar Association [IBA]/Oxford University Press 2002), preview, 1-120, especially 12 and 17; E. Bastida et al (eds), International and Comparative Mineral Law and Policy: Trends and Prospects (Kluwer Law International 2005), 265-267 and 278279, especially 265; T. C. Beierle and J. Cayford (n7); E. T. Bristol-Alagbariya (2010 [n2]), 40-41.
} 
Participation implies situations where citizens maybe requesting access to government-held information, serving on citizens' advisory panels, requesting or even agitating for administrative justice, instituting law suits on grounds of public interest, and all other variants of the concept that the governed could or must be engaged in their governance. ${ }^{1}$

PP informs, consults with, involves, collaborates with affected, concerned and interested citizens and citizengroups and empowers them in decision-making and decision-implementation processes. Participation is based on the belief that those who are affected by a decision have a right to be involved in the decision-making process, so as to have their aspirations, concerns, interests and values considered and/or addressed in the process. By and large, environmental democracy helps to guarantee environment justice, other forms of human rights associated with environmental rights and generic social justice. ${ }^{2}$

A broad array of techniques, processes and procedures of PP around the world underscore face-to-face deliberation, problem-solving and consensus-building of citizens and citizen-groups potentially affected by developmental PPPs, which are designed to achieve SD. Some fundamental challenges of environmental democracy, being administered by government environmental regulatory agencies, include lack of requisite finance and technical manpower (in the form of expertise), to respectively sponsor and manage government environmental regulatory programmes, so as to achieve the required widely acknowledged and accepted degree of Public Involvement (PI), namely interactive PI (public engagement), in the course of environmental democracy. These challenges should be addressed, because, for instance, if development project proponents like multinational oil and gas companies (MNOCs), financially sponsor environmental democracy programmes, they would invariably become judges in their own courts. Besides, governments should guarantee financial sufficiency of their environmental regulatory agencies so as to enable relevant personnel of these agencies to have regular capacitybuilding opportunities. Government regulators should always be trained and retrained. They should attend Environmental Assessment (EA) and PP capacity-building programmes nationally and internationally, which include those regularly being organised by the international headquarters of the International Association for Impact Assessment (IAIA) ${ }^{3}$ and the International Association for Public Participation (IAP2). ${ }^{4}$

The prevailing degree of PI, particularly environmental democracy in resources-rich developing countries suffering from the resource curse, is often lower than the widely acknowledged and accepted degree of public involvement. ${ }^{5}$ Based on Principle 10 of the Rio Declaration on Environment and Development, 1992, and elaborated in the Aarhus Convention, 1998, the globally recognised and accepted degree or standard of environmental democracy associated with developmental projects, whose operations impact negatively the environment and human wellbeing may be described as interactive PI, otherwise called public engagement'. As such, mere information gathering, information dissemination and consultation, do not constitute participation. Precisely, simply and squarely, PP is the extension of consultation, where directly-affected groups become collaborative or joint partners in designing and implementing of development project proposals, by participating in 'making' the decisions and accordingly contributing towards 'implementing' the decisions taken in the course of executing the project proposals. ${ }^{6}$

Government environmental regulatory agencies organising environmental democracy are also expected to carry out their duties and responsibilities in the public interest, which government is under obligation to promote and/or ensure, by virtue of the social contract of governance. ${ }^{7}$ This is more so, considering that citizens and citizengroups of global states are, in the course of ongoing participation explosion, increasingly becoming aware of the globally recognised and accepted degree or standard of environmental democracy associated with developmental projects, whose operations impact negatively the environment and their wellbeing. ${ }^{8}$

It may, at this juncture, also be necessary to state that PP, which environmental democracy is a key aspect of, accomplishes certain goals. These goals include educating and informing the public; incorporating public concerns

${ }^{1}$ D. N. Zillman et al (eds) (n8), preview, 1-120, 12 and 17; E. Bastida et al (eds) (n8), 265-267 and 278-279, especially 265.

${ }^{2}$ Ibid.

${ }^{3}$ Homepage of the IAIA $<$ https://www.iaia.org $>$ Accessed 7 February, 2020.

${ }^{4}$ Homepage of the IAP2 $<$ https://www.iap2.org $>$ Accessed 7 February, 2020.

${ }^{5}$ D. N. Zillman et al (eds) (n8), preview, 1-120, 12 and 17; E. Bastida et al (eds) (n8), 265-267 and 278-279, especially 265.

${ }^{6}$ UN Economic and Social Commission for Asia and the Pacific (UNESCAP), Public Involvement Guideline for Natural Resource Development Projects (UN 1997), 4-5; D. N. Zillman et al (eds) (8), especially the preview and 1-76; E. Bastida et al (eds) (8), 65-281; J. L. Creighton, The Public Participation Handbook: Making Better Decisions through Citizen Involvement, (Jossy-Bass 2005), especially 1; T. C. Beierle and J. Cayford (n7); International Institute for Environment and Development (IIED) and World Business Council for Sustainable Development (WBCSD), Breaking New Ground: Mining, Minerals, and Sustainable Development: The Report of the MMSD Project (Earthscan 2002); World Bank Group, 'Striking a Better Balance - The World Bank Group and Extractive Industries: The Final Report of the Extractive Industries Review, World Bank Group Management Response' <http://documents.worldbank.org/curated/en/961241468781797388/pdf/300010GLB.pdf> Accessed 7 February, 2020

${ }^{7}$ J. Rousseau, The Social Contract (Wordsworth Classics of World Literature) (Wordsworth Editions 1998); J. Rousseau, The Social Contract or Principles of Political Right (Aziloth Books 2011); McCombs School of Business, 'Social Contract Theory' $<$ https://ethicsunwrapped.utexas.edu/glossary/social-contract-theory > Accessed 7 February, 2019; the Preamble and Section 14 (2) (b) of the 1999 CFRN (as amended).

${ }^{8}$ Principle 1, Rio Declaration on Environment and Development, 1992. 
and values into decisions; improving the substantive quality of decisions; and ensuring consensus building as well as resolving existing and/or emerging problems such as resolving conflicts among conflicting interests; building trust among stakeholders, including government (public) institutions. Other goals of PP, especially environmental democracy, are arriving at more informed and better decisions (from inputs of members of the effected public); ensuring mutual commitment of stakeholders of development projects, such as development project proponents, members of the affected public and government regulatory authorities; providing access to government's administrative and judicial justice; implementing decisions of the public; ${ }^{1}$ and promoting and enhancing SD. ${ }^{2}$ Generally, to achieve the goals of PP, so as to guarantee its effectiveness, there are, among other strategies and indicators, pillars of participation, such as the spectrum of participation, core values of participation and code of ethics of participation, ${ }^{3}$ which enhance good decisions, strengthen good public sector governance (good governance [GG]) and particularly good environmental governance (GEG), which is an aspect of GG. ${ }^{4}$

Essentially, the success of PP, including environmental democracy, regarding development project proposals, such as EIOs development project proposals, basically depends on mutual respect, trust and partnership arising from efficient communication, understanding collaboration between and among major stakeholders of the proposals. These stakeholders are namely affected members of the public (such as the host or resources-bearing community), proponents of development projects (namely the private sector, such as industry or business corporation), and government organs (such as government's regulatory agencies and/or authorities). ${ }^{5}$

Environmental democracy is a key aspect of ongoing efforts of the entire global community, led by the UN, to achieve SD, in the interest of humanity as well as the overall interst of nature on Planet Earth. ${ }^{6}$ Consequently, the widely accepted need and degree of PP, especially environmental democracy, and increasing public awareness of this state of affaris in the course of ongoing global agenda to achieve SD that is masterminded by the UN, is considered by some as 'participation explosion'. ${ }^{7}$ The ever increasing awareness of members of the about PP and the prevailing nature of PP, especially environmenal democacy, in the ongoing era of SD, have, no doubt, occassioned what is now known as 'participation explosion' around the globe. Certainly, the entire global community is witnessing an era of participation explosion. ${ }^{8}$ By and large, the ongoing world-wide era of 'participation explosion'may be considered in the context of petroelum and other major natural resources (MNRs) extractive industrial operations (EIOs) taking place in resources-rich developing countries. ${ }^{9}$

Over the years and decades of its formal global expression, recognition and institutionalisation within Principle 10 of Rio Declaration on Environment and Development, 1992, the concept of environmental democracy has evolved and advanced, in an increasingly tremendous manner, in various countries, to become a developmental principle, law and practice. In the ongoing era of SD, environmental democracy is robustly and dynamically governing developmental processes, such as plans, polices and projects (including programmes [PPPs]), and thereby compelling such PPPs to have good outcomes in the public interest, by boosting SD. Environmental democracy ensures that citizens and communities, who are likely to be affected by developmental PPPs, are empowered to influence decisions regarding such PPPs affecting them and thus able to influence their future in relation to the PPPs. ${ }^{10}$ The developmental concept, principle, law and regulatory practice of environmental democracy requires the involvement of members of the public, namely citizens who may and/or are likely affected

\footnotetext{
The International Association of Public Participation (IAP2), 'IAP2 Spectrum of Public Participation' $<$ https://cdn.ymaws.com/www.iap2.org/resource/resmgr/pillars/Spectrum_8.5x11_Print.pdf $>$ Accessed 7 February, 2020.

${ }^{2}$ D. Warburton (ed), Community and Sustainable Development: Participation in the Future (Routledge 2016); E. T. Bristol-Alagbariya (2010 $[\mathrm{n} 2])$.

3 The 'Three $\quad$ IAP2, Pillars of Participation' $<$ https://cdn.ymaws.com/www.iap2.org/resource/resmgr/Communications/A3 P2 Pillars brochure.pdf $>$ Accessed 7 February, 2020.

${ }^{4}$ E. T. Bristol-Alagbariya (2010 [n2]), 330-331; E. T. Bristol-Alagbariya, Governance Towards Sustainable Development in Nigeria: The Role of Strategic Assessment of Decisions \& Actions (CEPMLP/DUP 2013) particularly xxxii-xxxiii, xxxv, xxxix, xl, xlii, 7-60, 71-72, 8896 and 265-293; J. L., Creighton (n14); E. T. Bristol-Alagbariya, 'Concepts, Theories and the Legal Principle of Permanent Sovereignty over Natural Wealth and Resources in Relation to Petroleum Development in Nigeria'. [2019] 4 (2) University of Port Harcourt Journal of Private Law, 189, 195-199 and 212; The World Bank, 'Guidance Notes on Tools for Pollution Management: Promoting Active Citizenry - Advocacy and Participation in Decision $<$ http://siteresources.worldbank.org/INTRANETENVIRONMENT/Resources/GuidanceNoteonAdvocacyandDecisionMaking.pdf $>$ Accessed 7 February, 2020.

${ }^{5}$ E. T. Bristol-Alagbariya (2010 [n2]), 20, 24-26, 28, 31, 33, 45, 325, 331-334 and 336; K. Omeje, High Stakes and Stakeholders: Oil Conflict and Security in Nigeria (Routledge 2016).

${ }^{6}$ Homepage of the Earth Charter Initiative $<$ http://earthcharter.org/> Accessed 7 February, 2020; Homepage of the UN $<$ https://www.un.org/en/ $>$ Accessed 7 February, 2020; Homepage of the UN on the Sustainable Development Goals $<$ https://www.un.org/sustainabledevelopment/ $>$ Accessed 7 February, 2020.

${ }^{7}$ D. N. Zillman et al (eds) (n8), 1-120, 12 and 17; E. Bastida et al (eds) (n8), 265-267 and 278-279, especially p. 265; The International Bank for Reconstruction and Development (The World Bank), The World Bank Participation Sourcebook (The World Bank, 1996); E. T. BristolAlagbariya (2010 [n2]), 18-19 and 40.

${ }^{8}$ Ibid.

${ }^{9}$ D. N. Zillman et al (eds) (8), especially the preview, 1-76 and 549-587; L. Barrera-Hernandez et al (eds), Sharing the Costs and Benefits of Energy and Resources Activity: Legal Change and Impact on Communities (Oxford University Press 2016).

${ }^{10}$ CIEL (n3).
} 
by developmental proposals, and thus are concerned and/or interested in such proposals, which have the potential to impact negatively on the environment and the human wellbeing, to participate (otherwise put, be engaged) in the decision-making process of such proposals, so as to promote and achieve SD in the course of the proposals. In the process, various variants, methods and models or techniques such as toolkits, ${ }^{1}$ of PP, particularly environmental democracy, are being designed and improved upon, in order to enhance the efficacy of the engagement of citizens and citizen-groups within the context and frameworks of PPPs as well as laws, regulations and regulatory practices, which are designed and administered to promote $\mathrm{SD},{ }^{2}$ towards achieving ecoenvironmentally-sound and socially-equitable SD. ${ }^{3}$ Consequently,_Principle 10 of Rio Declaration on Environment and Development, 1992, as elaborated in the Aarhus Convention, 1998, on PP, features as the global formal expression and landmark stipulation of the increasing public awareness of and the prevailing nature of environmental democracy being championed by the $\mathrm{UN}$, to promote $\mathrm{SD}$, in the interest of humanity, overall nature and the entire global community on Planet Earth.

4. Environmental Democracy: From Principle 10 of Rio Declaration on Environment and Development, 1992, to the Aarhus Convention, 1998, up to the UN Brisbane Declaration on Community Engagement, 2005, and the IAIA and IAP2 on Participation

The process of the development and advancement of environmental democracy may be variously considered, in a logical and sound manner. Environmental democracy may, for instance, be considered in the following contexts and perspectives: (a) Principle 10 of Rio Declaration on Environment and Development, 1992; (b) the Aarhus Convention, 1998; (c) the UN Brisbane Declaration on Community Engagement, 2005; (d) the IAIA and (e) IAP2 on Participation.

\subsection{Environmental Democracy Stipulated in Principle 10 of Rio Declaration on Environment and Development, 1992}

The Rio Declaration on Environment and Development, often shortened to Rio Declaration (namely a series of principles defining the rights and responsibilities of global states on issues of the environment and development), is a precise document produced at the $1992 \mathrm{UN}$ 'Conference on Environment and Development' (UNCED), also known as the 'Earth Summit', held at Rio de Janeiro, from 3 - 14 June, 1992. This Declaration is one of the three major agreements designed to guide future approaches of the global community towards SD and one of the five outcome documents of the UN Rio de Janeiro Earth Summit, which was convened to reconcile worldwide economic development and environmental protection. The rest of the three major agreements are the UN Agenda 21 and the Statement of Forest Principles. The rest of the outcome documents and legally binding instruments of the UN Rio de Janeiro Earth Summit are the UN Framework Convention on Climate Change and the Convention on Biological Diversity. ${ }^{4}$

Principle 10 of Rio Declaration on Environment and Development, 1992, provides thus:

Environmental issues are best handled with the participation of all concerned citizens, at the relevant level. At the national level, each individual shall have appropriate access to information concerning the environment that is held by public authorities, including information on hazardous materials and activities in their communities, and the opportunity to participate in decision-making processes. States shall facilitate and encourage public awareness and participation by making information widely available. Effective access to judicial and administrative proceedings, including redress and remedy, shall be provided. ${ }^{5}$

The above-stated Principle constitutes benchmarked international stipulations on environmental democracy around the globe. This Principle features as the global landmark soft law instrument on environmental democracy, based on which environmental democracy further advanced in the developed countries that have well-established land-use planning procedures. Accordingly, the same Principle provides necessary and significant background for environmental democracy to systematically evolve and sustainably develop in developing and least developed countries that never had relatively well-established land-use planning procedures as their advanced counterparts, specifically concerning issues of the environment and development, such as formal Environmental Assessment

\footnotetext{
${ }^{1}$ E. T. Bristol-Alagbariya (2010 [n2]), 29, 40, 328 and 336; K. Callahan, 'Participation: Models and Methods' [2007] 30 (11) Journal of Public Administration, $1179 \quad-1196$; Tompkins County, New York, 'Public Participation Toolkit' $<$ http://tompkinscountyny.gov/tccp/publicparticipation> Accessed 7 February, 2020.

2 IGI Global - Disseminator of Knowledge, 'What is Environmental Democracy' < https://www.igi-global.com/dictionary/potentialparticipation-urban-planning/10061> Accessed 7 February, 2020.

${ }^{3}$ M. Mason, Environmental Democracy: A Contextual Approach (Earthescan1999).

${ }^{4}$ UN SD Goals Knowledge Platform', 'United Nations Conference on Environment and Development (UNCED), Earth Summit' $<$ https://sustainabledevelopment.un.org/milestones/unced $>$ Accessed 7 February, 2020.

5 UN Audiovisual Library of International Law, 'Rio Declaration on Environment and Development' $<$ https://legal.un.org/avl/pdf/ha/dunche/rio ph e.pdf $>$ Accessed 7 February, 2020.
} 
(EA), which provides a robust framework for environmental democracy. ${ }^{1}$

\subsection{Environmental Democracy in the Context of the Aarhus Convention of 1998}

The Aarhus Convention on access to information, PP in decision-making and access to justice in environmental matters, was adopted on June 25, 1998, in the Danish City of Aarhus, at the Fourth Ministerial Conference in the 'Environment for Europe' process, under the auspices of the UN Economic Commission for Europe [UNECE]). ${ }^{2}$

The three components or pillars of environmental democracy, espoused or stated in Principle 10 of Rio Declaration on Environment and Development, 1992, namely on (a) access to information, (b) PP in decisionmaking, and (c) access to justice in environmental matters, are enshrined and elaborated in the Aarhus Convention. ${ }^{3}$ The Convention is widely and authoritatively considered as the most elaborate expression, milestone and landmark of Principle 10 of Rio Declaration on Environment and Development, 1992; even as the Seventh UN SecretaryGeneral (1 January, 1997 - 31 December, 2006), Kofi Annan, describes it as such, and therefore the most ambitious venture on environmental democracy undertaken under the auspices of the UN. ${ }^{4}$

The universal context or feature of the Aarhus Convention is embedded in its rights-based and nondiscriminatory ${ }^{5}$ orientation and procedural requirement towards boosting environmental democracy regarding participation of citizens and the general public (including future generations). ${ }^{6}$ Given its universal feature, whereas most multilateral environmental agreements cover responsibilities that parties have to each other, the Aarhus Convention ascribes responsibilities of parties to the Convention to the public. Furthermore, whereas the Convention applies to countries of the ECE, non-ECE countries may accede to become parties to the Convention, subject to the provisions of Article 19,7 especially 19 (3) and 19 (4) of the Convention, as well as by meeting other criteria expressed in other relevant Articles of the Convention, for instance, its Article 9 (3) concerning access to environmental justice. ${ }^{8}$ Such an all-encompassing right of accession makes the Aarhus to be global in nature and orientation.

\subsection{Environmental Democracy and the UN Brisbane Declaration on Community Engagement, 2005}

Principle 10 of Rio Declaration on Environment and Development, 1992, as profoundly expressed in the Aarhus Convention, was further espoused in the UN Brisbane Declaration on Community Engagement, 2005, which resulted from the International Conference on Engaging Communities, jointly held by the UN and the Queensland Government, Australia, at the Brisbane Convention and Exhibition Centre, Brisbane, the capital of Queensland, Australia, from $14-17$ August, 2005. ${ }^{9}$ This Conference attracted representatives of countries and communities, including indigenous peoples, international institutions, as well as national and state governments and local governments, academic institutions, and business and civil society organisations from across the world. ${ }^{10}$

Delegates and attendees of the Brisbane Conference echoed and reinforced the universal interest and importance of community engagement, founded in the inherent dignity of people and the values, rights and responsibilities of all peoples expressed in the Universal Declaration on Human Rights, 1948. They affirmed that community engagement was critical to good, effective, transparent and accountable public sector governance as well as community governance and private sector governance. They also affirmed that effective engagement

\footnotetext{
${ }^{1}$ A. Gilpin, Environmental Impact Assessment (EIA): Cutting Edge for the Twenty-First Century (Cambridge University Press 1995), 2; E. T. Bristol-Alagbariya (2010 [n2]), 146-151 and 156-170.

${ }^{2}$ Convention on Access to Information, Public Participation in Decision-Making and Access to Justice in Environmental Matters, done at Aarhus, Denmark, on 25 June $1998<$ https://www.unece.org/fileadmin/DAM/env/pp/documents/cep43e.pdf > Accessed 7 February, 2020.

${ }^{3}$ Area of the homepage of the European Commission captioned 'The Aarhus Convention' $<$ https://ec.europa.eu/environment/aarhus/index.htm $>$ Accessed 7 February, 2020

${ }^{4}$ UNECE, 'AARHUS CONVENTION: Convention on Access to Information, Public Participation in Decision-making and Access to Justice in Environmental Matters - Quotable' <https://www.unece.org/fileadmin/DAM//env/pp/contentofaarhus.htm> Accessed 7 February, 2020; S. Stec et al, The Aarhus Convention: An Implementation Guide (2000) v.

${ }^{5}$ Article 3 (9) and Article 2 of the Aarhus Convention. Article 3 (9) of the Convention provides that within the scope of the relevant provisions of this Convention, the public shall have access to information, have the possibility to participate in decision-making and have access to justice in environmental matters without discrimination as to citizenship, nationality or domicile and, in the case of a legal person, without discrimination as to where it has its registered seat or an effective centre of its activities. Article 2 (4) of the Convention defines 'The Public' as one or more natural or legal persons, and, in accordance with national legislation or practice, their associations, organizations or groups. Article 2 (5) of the Convention defines the 'Public Concerned 'as the public affected or likely to be affected by, or having an interest in, the environmental decision-making; for the purposes of this definition, non-governmental organizations promoting environmental protection and meeting any requirements under national law shall be deemed to have an interest. Article 3 of the Convention is captioned 'General Provisions', while Article 2 of the Convention is entitled 'Definitions'.

${ }^{6}$ Article 1 of the Aarhus Convention, captioned 'Objective'.

${ }^{7}$ Article 19 of the Aarhus Convention, entitled 'Ratification, Acceptance, Approval and Accession'

${ }^{8}$ Article 9 of the Aarhus Convention, captioned 'Access to Justice'.

${ }^{9} \mathrm{UN}$ and the Queensland Government, Australia, Handbook (International Conference on Engaging Communities, 14 -17 August, 2005: An Initiative of the UN and the Queensland Government, Brisbane Convention \& Exhibition Centre, Queensland, Australia) (UN and the Queensland Government, Australia, 2005).

${ }^{10}$ The UN Brisbane Declaration on Community Engagement, 2005, <https://www.lcsansw.org.au/documents/item/330> Accessed 7 February, 2019.
} 
generated better decisions, as well as delivered sustainable economic, environmental, social and cultural benefits. Accordingly, they recognised that effective community engagement enabled the free and full development of the potentials of humans and fostered human relations on the basis of mutual understanding, trust and respect, as well as facilitated the sharing of responsibilities, and created more inclusive and sustainable communities. The delegates and attendees of the Brisbane Conference endorsed the core principles of integrity, inclusion, deliberation and influence in community engagement. They appreciated their host Queensland Government, and requested the UN to build on the success and legacies of the conference, so as to assist countries and communities around the globe to foster effective community engagement practices and to support research and development and information dissemination on community engagement around the world. ${ }^{1}$

From the foregoing, the UN Brisbane Conference on Community Engagement, 2005, and the Declaration made therein may be described as consolidating citizens' engagement. The conference and declaration consider community engagement as an aspect of citizens' engagement or PP, towards good, responsible, transparent and accountable governance in global states and thus good environmental governance (GEG) as well as improved and/or efficient environmental democracy, environmental justice and social equity associated with developmental PPPs, particularly EIOs, taking place in local communities and societies around the globe, especially resourcesrich developing countries.

\subsection{Environmental Democracy in the Context and Framework of the International Association for Impact Assessment (IAIA)}

The International Association for Impact Assessment (IAIA), organised in 1980 to bring together researchers, practitioners and users of various types of Impact Assessment (IA) from all parts of the world, is the leading global network on best practice in the use of IA for informed decision-making regarding PPPs. ${ }^{2}$ The IAIA is an organisation with a voluntary membership of professionals from a diverse array of interests and organisations, all of whom are concerned with environmental stewardship and sustainability, so as to protect and not harm the environment, variety of peoples and other resources of nature on Planet Earth. ${ }^{3}$ Its membership, numbering over 1700 from over 120 countries, represents many disciplines and professions. The vision of the IAIA is to use IA for informed decision-making regarding PPPs around the globe. Its mission is to provide a world-wide forum for advancing innovation and communication of best practice in all forms of IA, in order to further the development and advancement of national, regional and global capacity in IA ${ }^{4}$ Consequently, IAIA and its array of members and chapters around the globe, operate on the conviction and belief that IA is a tool for high environmental quality and social equity, towards achieving or realising environmentally sound and socially equitable sustainable development. IAIA and its globalised chapters and members embark on IA activities in the spirit and professionally guided operational standard and practice that IA is a practical tool for helping to meet contemporary needs of humanity, without compromising the ability and opportunities of future generations of humanity to meet their own needs. On this note, in its specialised and distinctive framework, as governed by its core values, IAIA promotes the application of integrated and participatory approaches, strategies and techniques to IA conducted to achieve highest professional quality and standard. Therefore, IAIA and its global community of IA chapters, affiliates and practitioners concern themselves about the policies, priorities, practices and challenges shaping impact assessment in countries, to contribute in a sound and meaningful manner in IA professionalism, ongoing processes as well as towards the continuous advancement and future directions of the IA process and practice around the globe. ${ }^{5}$

From the foregoing, IAIA may be described as an organisation that promotes PP in the rubrics of environmental democracy, associated with environmental assessment (EA) and generic IA of developmental PPPs, towards promoting and actualising SD, especially environmentally sound and socially equitable SD in local communities, countries and regions around the globe.

\subsection{Public Participation in Decision-Making in the Context and Framework of the International Association for Public Participation (IAP2)}

The International Association for Public Participation (IAP2), is a worldwide association and global leader in PP. The association is comprised of people, who are engaged in the philosophy and practice of PP, towards making and implementing decisions that affect members of the public, so as to achieve good decisions and GG, as well as promote and safeguard public interest, while advancing the profession and practice of PP. ${ }^{6}$ In the ongoing and ever increasing era of globalisation, when citizens are being empowered by their own governments to take part in decision-making processes so as to impact on the state, their wellbeing and the wellbeing of their future generations,

${ }^{2}$ Homepage of the IAIA (n11).

${ }^{3}$ IAIA, 'About IAIA'<https://www.iaia.org/about.php> Accessed 7 February, 2019.

${ }^{4}$ Ibid.

${ }^{5}$ Ibid.

${ }^{6}$ Homepage of the IAP2 (n12).
} 
homelands, communities, cities, countries and the world at large, the IAP2 is advancing the profession and practice. $^{1}$

The association promotes PP in relation to individuals, governments, institutions and other entities that affect public interest in countries around the world. Through its members, the IAP2 develops practical tools of good practices on PP, to help businesses, communities, governments, and other institutional or organisational entities around the world to improve their decisions, by involving those affected by such decisions. By and large, the IAP2 promotes the fact that citizens' involvement (PI) in decision-making is not merely an attribute of democracy but also an essential ingredient of GG based on the transparency and accountability of governments to the governed. ${ }^{2}$

The mission of the IAP2 is to advance and extend the practice of PP through professional development, certification, standards of practice and indicators of effectiveness such as its code of ethics, core values and spectrum of participation, ${ }^{3}$ as well as by virture of its dynamic and goal-oriented form of advocacy, key initiatives and various forms of activities being held in association with strategic PP-oriented organisations and partners around the globe. ${ }^{4}$ The initial mission of the association includes convening annual conferences and promoting core values and best standards and practices associated with PP in government and industry decisions which affect the public. ${ }^{5}$

The IAP2, whose international headquarters is at Denver, Colorado, USA, was established in 1990, as a nonprofit corporation, in response to the rising global need for and interest in PP. ${ }^{6}$ It was founded as the International Association of PP Practitioners (IAP3), consequent upon which its founding members assembled a Board of Directors, developed its by-laws and policies and organised its first annual conference in Portland, Oregon, USA, in 1992. Thereafter, the association changed its name to IAP2, to reflect the growing diversity and inclusiveness of its world-wide membership. Its membership grew from about 300 in 1992, to over 1,050 in 2007, spreading over 26 countries. Accordingly, the IAP2's regions were formed in 2010, in order to better meet its needs and the realities of its calling as a worldwide PP organisation. ${ }^{7}$ These regions are now seven, namely Australia (covering Australia and New Zealand), Canada, Indonesia, Italy, Latin America (covering Central America, South America and the Caribbean), Southern Africa (covering Angola, Botswana, Lesotho, Madagascar, Malawi, Mauritius, Mozambique, Namibia, South Africa, Swaziland, Zambia and Zimbabwe) and the USA. ${ }^{8}$ The association is indeed consistently growing and entrenching itself as a global leader in its dedicated and specialised field of PP. ${ }^{9}$

The IAP2, organised around its executive director, a high-calibre board of directors, a strong international headquarters, special committees, several professional sectors, regions and country-wide chapters and the rest of its members from non-chapter countries, conducts its activities to achieve the following objectives: (a) Boost professional development of people working on PP; (b) Educate decision-makers about the value of PP; (c) Help the public play effective roles in PP processes; and (d) Continue to define, review and enhance benchmarked interntional stadards and practices on PP. ${ }^{10}$

The existence of the IAP2 is thus directly or indirectly influencing the course of citizens' participation in decsion-making process and the implementation of PPPs affecting the wellbeing of citizens and society at large. Nations of the world, especially developing countreis, are therefore being influenced by the IAP2 to imbibe the doctrine and practice of greater inclusiveness in decision-making processes, rather than excluding their citizens from decision-making processes, so as to promote good decisions and GG, in the global march towards SD. ${ }^{11}$

The IAP2 may thus be described as a global leader in PP, whose wide spectrum of members and associates deal with generic PP, which is broader than environmental democracy that is limited to PP in environmental matters, so as to promote good decisions, generic public interest and GG around the world, in the ongoing march of the entire global community towards SD.

\section{Resources-rich Developing Countries and Environmental Democracy}

Resources-rich developing countries are countries which are richly endowed with MNRs, namely oil and gas and other mining and mineral resources EIOs, from which wealth is derived by governments of such countries to

\footnotetext{
${ }^{1}$ IAP2, 'History' < https://www.iap2.org/page/history> Accessed 7 February, 2019.

${ }^{2}$ IAP2 PP Training captioned 'The Standard for Effective Public Involvement ...! Good Decisions Don't Just Happen!', held at 801 North Quincy, $\quad 3^{\text {rd }} \quad$ Floor, $\quad$ Arlington, $\quad$ Virginia $\quad 22203, \quad 11 \quad-\quad 2014$, <https://cdn.ymaws.com/www.iap2.org/resource/resmgr/Training/IAP2_ARLINGTON_VA_MAY_12_16_pdf $>$ Accessed 7 February, 2020. 3 The IAP2, 'Three Pillars of - - Effective Participation' $<$ https://cdn.ymaws.com/www.iap2.org/resource/resmgr/Communications/A3_P2_Pillars_brochure.pdf $>$ Accessed 7 February, 2020.

${ }^{4}$ IAP2, 'About Us'<https://www.iap2.org/page/about> Accessed 7 February, 2020.

${ }^{5}$ Ibid.

${ }^{6}$ IAP2 PP Training captioned 'The Standard for Effective Public Involvement ...! Good Decisions Don't Just Happen!' (n49).

${ }^{7}$ IAP2, 'History' (n48).

${ }^{8}$ IAP2, 'IAP2 Around the World' < https://www.iap2.org/page/membership > Accessed 7 February, 2020.

${ }^{9}$ IAP2, 'History' (n48).

${ }^{10}$ IAP2 PP Training, captioned 'The Standard for Effective Public Involvement ...! Good Decisions Dont Just Happen!' (n49); E. T. BristolAlagbariya (2010[n2]), 91.

${ }^{11}$ T. C. Beierle and J. Cayford (n7), 1-33, especially, 1 and 3; E. T. Bristol-Alagbariya (2010 [n2]), 90-91.
} 
sustain their political economies. ${ }^{1}$ However, in spite of the enormous wealth accruing to the governments of resources-rich developing countries, from the exploitation and extraction, otherwise put development, of their abundant MNRs, these countries are characteristically plagued by the resource curse, which demonstrates failure of resources-rich developing countries to fully benefit from their abundant MNRs, as well as failure of governments of these countries to effectively respond to the needs of the citizenry in the respective countries. The resource curse is called the Dutch disease, resource-trap, the paradox of plenty. ${ }^{2}$ It is called the Dutch disease because it is a situation which occurred in the Netherlands, when abundant gas resources were discovered therein, whereby it refers to any country that discovers natural resources in abundance but got trapped by the paradox of such enormous resources. ${ }^{3}$

The phrase or term 'resource curse', said to have been first coined by a British economist, Richard M. Auty, in 1993, is more often considered as describing the phenomenon of how and when a poor country discovers abundant MNRs and thus derives enormous wealth from the extraction of the resources, but develops more slowly than countries that are not so endowed with MNRs, due to the mismanagement of the enormous wealth accruing to it by its bad and often authoritarian government. In the process, the resources-rich country generates many negative consequences (arising from the mismanagement of enormous wealth), which characterises it in relation to the irony of its fate. ${ }^{4}$ Such paradoxical characteristic consequences or features of the resource curse include poverty in the midst of plenty, environmental degradation, devastation of ecology and ecosystem as well as despoliation of ecosystem services, abuse of human rights, particularly violations of environmental rights, and violent conflicts, crises and civil wars, which are associated with EIOs of MNRs in resources-rich developing countries. ${ }^{5}$ Usually also, environmental democracy is characteristically weak in resources-rich developing countries. Governments of resources-rich developing countries are also not able to perform their social responsibilities, based on the social contract between the institution of government and the governed. As such, key government officials and functionaries of resources-rich developing countries are known to mismanage, misappropriate and primitively accumulate the enormous wealth accruing to their countries from EIOs of MNRs, which wealth should otherwise be utilised for overall public good, namely the all-encompassing benefit and wellbeing of their citizens and all-embracing development and prosperity of their countries. These negative characteristic consequences or features of the resource curse are associated with developing countries, which are abundantly endowed with MNRs, where there are cases such as blood petroleum (oil and gas) resources (as in the crystal-clear case of Nigeria) ${ }^{6}$ and blood diamonds (as evident in the case of Sierra Leone), ${ }^{7}$ among such other

${ }^{1}$ C. Tan and J. Faundez (eds), Natural Resources and Sustainable Development: International Economic Law Perspectives (Edward Elgar Publishing 2017); R. Perman et al, Natural Resource and Environmental Economics (Addison Wesley/Pearson Education 2011); T. Jackson, Prosperity without Growth: Economics for a Finite Planet (Earthscan 2011); T. Jackson, Prosperity without Growth?: The Transition to a Sustainable Economy (Sustainable Development Commission 2009).

2 J. Chen, 'The Resource Curse'<https://www.investopedia.com/terms/r/resource-curse.asp > Accessed 7 February, 2020 ; The Natural Resource Governance Institute, 'The Resource Curse: The Political and Economic Challenges of Natural Resource Wealth' $<$ https://resourcegovernance.org/sites/default/files/nrgi_Resource-Curse.pdf $>$ Accessed 7 February, 2020; S. M. Patrick, Why Natural Resources Are a Curse on Developing Countries and How to Fix It' $<$ https://www.theatlantic.com/international/archive/2012/04/why-naturalresources-are-a-curse-on-developing-countries-and-how-to-fix-it/256508/> Accessed 7 February, 2020; P. J. Stevens, 'The Resource Curse Revisited Appendix: A Literature Review' [2015] The Royal Institute of International Affairs, 1-42; F. van der Ploeg, 'Natural Resources: Curse Or Blessing?' [2011] 49 (2) Journal of Economic Literature, 366-420.

${ }^{3}$ Ibid; T. L. Karl, The Paradox of Plenty: Oil Booms and Petro-States (University of California Press 1997); I. Gary and T. L. Karl, Bottom of the Barrel: Africa's Oil Boom and the Poor (Catholic Relief Services 2003); P. Collier, The Bottom Billion: Why the Poorest Countries Are Failing and What Can Be Done About It (Oxford University Press 2007).

${ }^{4}$ R. M. Auty, Sustaining Development in Mineral Economies: The Resource Curse Thesis (Routledge 1993); A. Perry, 'Brief History: The Resource Curse' <http://content.time.com/time/magazine/article/0,9171,1997460,00.html> Accessed 7 February, 2020 ; R. M. Auty and H. Furlonge, The Rent Curse: Natural Resources, Policy Choice, and Economic Development (Oxford University Press 2019); K. Omeje (ed), Extractive Economies and Conflicts in the Global South: Multi-Regional Perspectives on Rentier Politics (Ashgate Publishing 2008); K. Omeje (2016 [n21]); K. Omeje (ed), State-Society Relations in Nigeria: Democratic Consolidation, Conflicts and Reforms (Adonis \& Abbey 2007); Principle 25, Rio Declaration on Environment and Development, 1992, which provides that 'peace, development and environmental protection are interdependent and indivisible'.

${ }^{5}$ O. V. C. Okene (ed), Readings in Law and Policy (Current Issues and Trends): (In Commemoration of the Golden Jubilee of Rivers State (1967-2017) (Faculty of Law, Rivers State University 2017); N. Bassey, Oil Politics: Echoes of Ecological Wars (Daraja Press 2016); C. Obi and S. A. Rustad (eds), Oil and Insurgency in the Niger Delta: Managing the Complex Politics of Petro-violence (Zed Books 2011); G. S. Boughton, Black Gold - Black Scorpion: Biafra Remembered (GB Publishing.org 2015); I. Bannon and P. Collier (eds), Natural Resources and Violent Conflict: Options and Actions (The World Bank 2003); T. Tamuno, Oil Wars in the Niger Delta 1849 -2009 (Stirling-Horden Publishers 2011); J. G. Frynas, Oil in Nigeria: Conflict and Litigation between Oil Companies and Village Communities (Transaction Publishers 1993 ); Z. Adangor, Federalism and Natural Resource Governance in Nigeria: An Agenda for Constitutional Reform (Sibon Books 2015); V. Egwemi et al (eds), Federalism, Politics and Minorities in Nigeria Essays in Honour of Professor G. N. Hembe (Bahiti and Dalila Publishers 2014); S. Azaike, Inequities in Nigerian Politics (Treasure Communications Resource 2003); R. T. Suberu, Ethnic Minority Conflicts and Governance in Nigeria (Spectrum 2003); R. T. Suberu, Federalism and Ethnic Conflict in Nigeria (United States Institute of Peace 2001).

${ }^{6}$ M. Klare, Blood and Oil (American Empire Project (Holt Paperbacks 2005); V. E. Eromosele, Nigerian Petroleum Business: A Handbook (WIT Press 1997); O. Douglas and I. Okonta, Where Vultures Feast: Shell, Human Rights, and Oil in the Niger Delta (Sierra Club 2001).

${ }^{7}$ G. Campbell, Blood Diamonds: Tracing the Deadly Path of the World's Most Precious Stones (Westview Press 2002); A. M. Barrie, Dilemma of A Nation: Sierra Leone Blood Diamonds (A. M. Barrie Press Multi Services 2012); H. Ross and K. Marafono, From SAS to Blood Diamond Wars (Pen \& Sword Military 2011); Al J. Venter, Sierra Leone: Revolutionary United Front: Blood Diamonds, Child Soldiers and Cannibalism, 
negative characteristic features and consequences of the mismanagement of the enormous wealth accruing from the rich MNRs of a country. It is also important to note that the resource curse inhibits SD and threaten the future of these countries, as sovereign states. ${ }^{1}$ Nigeria should be worried for being a classic example of a resources-rich developing country plagued by the resource curse, especially in the context of its abundant petroleum resources being developed and extracted for its wellbeing and the wellbeing of its component geopolitical units and entire citizens. $^{2}$

Studies, standards and practices around the world are increasingly demonstrating that EIOs essentially inhibit SD. ${ }^{3}$ However, such studies, standards and practices indicate that EIOs may be advantageous when they are implemented well, to preserve the rights of people they directly affect, and if the benefits they generate are wellused. ${ }^{4}$ In other words, if EIOs are properly executed in conformity with benchmarked international guidelines, standards and practices governing the global extractive industrial sector, ${ }^{5}$ they can contribute to poverty reduction and environmentally-sound, ecologically-centred and socio-economically equitable SD. ${ }^{6}$

\section{Environmental Democracy, Sustainable Petroleum Development and Sustainable Development of the Oil- rich Delta Region and the Country}

It has already been stated under the foregoing sub-heading that EIOs inhibit SD, but that these operations can contribute to SD if they are carried out in conformity with benchmarked international standards and practices. It was also explained that environmental democracy is characteristically weak in resources-rich developing countries plagued by the resource curse, and this is the case regarding petroleum resources development operations (PRDOs) in the oil-rich communities of the minority ethnic Delta region of Nigeria.

The most visible, enriched and often celebrated aspect of environmental democracy in the course of PRDOs in the oil-rich Nigerian Delta region is that concerning environmental assessment (EA) of the resources development projects in the oil producing communities of the region. In this regard, public involvement (PI), most especially in the form of Community Involvement (CI) may take place during certain stages of the prevailing Environmental Impact Assessment (EIA) process in Nigeria, as stipulated in the country's EIA Act and its accompanying generic EIA sectoral and procedural guidelines, ${ }^{7}$ including the sectoral guidelines of various sectors of the Nigerian economy. ${ }^{8}$ For example, among these sectoral guidelines are the EIA guidelines and standards for the Petroleum Industry in Nigeria, ${ }^{9}$ as well as EIA the guidelines of the oil and gas sector of Nigeria's economy. ${ }^{10}$

Concerning environmental democracy in the context of various stages of the EIA process, PI typically occurs during the scoping and review stages of the EIA process as well as at any other stage requiring the involvement of the public, who may be affected by, concerned about or interested in the development proposal associated with EIA process. ${ }^{11}$ For instance, the United Nations Environment Programme (UNEP [the voice of the UN system on the environment]), outlines when PI is in key stages of the EIA process, such as the stage of screening, scoping, impact analysis, review, project implementation. Project implementation stages include monitoring and follow-up stages of the execution phase of development projects. Specific provisions of Nigeria's EIA Act on PI include

1991-2002 (History of Terror Series) (Pen \& Sword Military 2018).

${ }^{1}$ A. J. Venables, 'Using Natural Resources for Development: Why Has It Proven So Difficult?' [2016] 30 (1) The Journal of Economic Perspectives, 161-183; H. Habila, Oil on Water (Penguin Books 2011); T. Tamuno (n63); J. Hill, Nigeria Since Independence: Forever Fragile? (Palgrave Macmillan 2012); R. Nwadiaru, Nigeria: A Failed State: Profound Treatise on a Crippled Giant (Tate Publishing 2012); Z. Adangor (n63); V. Egwemi et al (eds) (n63); S. Azaike (n63); R. T. Suberu (2003 [n63]); R. T. Suberu (2001 [n63]).

${ }^{2}$ E. C. Onwuka, 'Oil Extraction, Environmental Degradation and Poverty in the Niger Delta Region of Nigeria' [2005] 62 (6) International Journal of Environmental Studies, 655-662; The World Bank Population and Human Resources Division Western Africa Department Africa Region, Nigeria Poverty in the Midst of Plenty The Challenge of Growth with Inclusion A World Bank Poverty Assessment (The World Bank 1996); G. Eweje, Environmental Costs and Responsibilities from Oil Exploitation in Developing Countries: The Case of the Niger Delta of Nigeria' [2006] 69 (1) Journal of Business Ethics, 27-56; I. Gary and T. L. Karl (n62); W. Ascher, Why Governments Waste Natural Resources: Policy Failures in Developing Countries (John Hopkins University Press 1999).

${ }^{3}$ World Bank Group (n14)

${ }^{4}$ Ibid.

${ }^{5}$ P. D. Cameron and M. C. Michael, Oil, Gas, and Mining: A Sourcebook for Understanding the Extractive Industries (World Bank Group 2017).

${ }^{6}$ E. T. Bristol-Alagbariya (2010 [n13]) 83-101, especially 100-101.

${ }^{7}$ Federal Environmental Protection Agency (FEPA), Environmental Impact Assessment Procedural Guidelines (FEPA 1995).

${ }^{8}$ FEPA, Environmental Impact Assessment Sectoral Guidelines for Oil and Gas Industry Projects (FEPA 1995); FEPA, Sub-Sectoral Guidelines for Petroleum Refining' in Environmental Impact Assessment Sectoral Guidelines for Oil and Gas Industry Projects (FEPA 1995); FEPA, Environmental Impact Assessment Sectoral Guidelines: Manufacturing Industries (FEPA 1995); Federal Ministry of Environment (FMEnve), National Guidelines for Environmental Impact Assessment Act (Act 86. 1992): Mining (FMEnve 2013).

${ }^{9}$ Department of Petroleum Resources (DPR), Environmental Guidelines and Standards for the Petroleum Industry in Nigeria (EGASPIN) (DPR 1991/2002 [Revised 2002]).

${ }^{10}$ FEPA, Environmental Impact Assessment Sectoral Guidelines for Oil and Gas Industry Projects (n73); FEPA, Sub-Sectoral Guidelines for Petroleum Refining' in Environmental Impact Assessment Sectoral Guidelines for Oil and Gas Industry Projects (n73).

${ }^{11}$ M. McCabe and B. Sadler (eds), Studies of EIA Practice in Developing Countries: A Supplement to the UNEP Training Resource Manual (Division of Technology, Industry and Economics [DTIE] UNEP 2002), editorial note; M. McCabe and B. Sadler (eds), Environmental Impact Assessment Training Resource Manual, (The Economic and Trade Branch, Division of Technology, Industry and Economics (DTIE), UNEP, 2002). 
Section 1(c), Section 7, Section 8, and Section 9 of the Act. Other relevant sections of Nigeria's EIA Act indicating

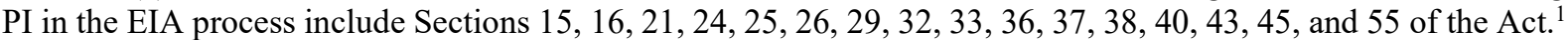
The provisions of these sections of the EIA Act reflect how and when citizens and citizen-groups, which include those of the oil-producing communities, may be involved in the EIA process of development proposals affecting the environment and their wellbeing.

PI also takes place during EIA in Nigeria, following the display of public notices at strategic places within the affected state capitals and capitals of affected Local Government Areas (LGAs) on mandatory draft EIA study reports (of development proposals), which are prepared by project proponents in compliance with the provisions of Section 24 (2) of the EIA Act, when members of the public take the initiative of writing and filing their comments with the apex EIA regulatory body. That is the EIA Department of the Federal Ministry of Environment [FMEnve], which is superintended over by the National Environmental Standards and Regulations Enforcement Agency [NESREA. ${ }^{2}$ By filing such written comments within the time provided in the EIA Act, or when a report, considered as a source of information within the contemplation of Section 18 (2) of the Act (i.e., the screening process of development proposals not indicated in the mandatory study list), is made, mediation or panel review sessions may be convened by the EIA Department of the FMEnve. By filing such written comments within the time provided in the EIA Act, or when a report, considered as a source of information within the contemplation of Section 18 (2) of the Act (i.e., the screening process of development proposals not indicated in the mandatory study list), is made, the apex EIA regulatory body (the EIA Department of the FMEnve) may convene a mediation or panel review session of the EIA process of the development proposal, in response to the comments, objections, reports or any other relevant information filed by members of the public. Such members of the public may be citizens or citizen-groups as EIA experts and practitioners, affected local communities, community-based organisations and public-spirited environmental NGOs. ${ }^{3}$

In the EIA process also, PI may further take place during follow-up and monitoring programmes of implementation phase of development proposals. ${ }^{4}$ It is important to explain that follow-up and monitoring schemes are aspects of environmental protection and management programmes. Whereas, follow-up schemes are one-off measures dedicated to specific issues that are identified and approved by the apex government regulatory agency (the EIA Department of the FMEnve) to be so addressed by follow-up measures, monitoring schemes are generic; as such, monitoring process takes place throughout the implementation stage of development proposals. ${ }^{5}$

During the EIA processes, the apex EIA regulatory agency is traditionally or usually accompanied, supported and assisted in the exercise of its constitutional and statutory functions and responsibilities, by government EIA regulatory agencies of affected states and local governments. Various states of Nigeria have their environmental protection agencies (EPAs) or EIA Departments often within their respective Ministries of Environment, while local governments have Environmental Protection Committees (EPCs). ${ }^{6}$ By and large, EPAs of various states and EPCs of LGs of Nigeria perform their roles and responsibilities in conjunction with or at the behest of the apex EIA regulatory agency, which is superintended over by NESREA in Nigeria's federal civil service system. ${ }^{7}$

Furthermore, community involvement (CI), which is an aspect of PI, may take place in Nigeria when petroleum (oil and gas) resources development project proponents take steps to comply with the country's Oil

\footnotetext{
${ }^{1}$ Section 15 of the EIA Act, Cap E12 LFN 2004, is captioned 'Environmental Assessment Process'; Section 16: 'Factors for Consideration of a Review Panel'; Section 21: 'Decision of the Agency'; Section 24: 'Public Notice'; Section 25: 'Decision of Council'; Section 26: 'Referral to Council.', and Section 29 of the Act is captioned 'Referral by Council'. Also, Section 32 of the Act is captioned 'Determination of Parties'; Section 33: 'Mediation'; Section 36: 'Assessment by Review Panel'; Section 37: 'Hearing of Witnesses'; Section 38: 'Public Notice'; Section 40: 'Design and Implementation'; Section 43: 'Joint Panel Review'; Section 45: 'Conditions', and Section 55 of the Act is captioned 'Public Registry'

${ }^{2}$ M. McCabe and B. Sadler (eds) (n76), 69

${ }^{3}$ Ibid; Sections 21(b) (ii) and 33 and 34 of the EIA Act, LFN 2004

${ }^{4}$ Section 21(b) (ii), Section 33 and Section 34 of the EIA Act, Cap E12 LFN 2004; M. McCabe and B. Sadler (eds) (n76), 69.

${ }^{5}$ A. Morrison-Saunders and J. Arts (eds), Assessing Impact: Handbook of EIA and SEA Follow-up (Earthscan, 2006); Economic Commission for Africa (ECA), Review of the Application of Environmental Impact Assessment in Selected African Countries (ECA 2005), especially xvi, 46, 73-74; Section 40 (d) of the EIA Act, LFN 2004, on implementation of EIA follow-up programme; Section 40 of the EIA Act is captioned 'Design and implementation'; Section 7 and Section 8 of the National Environmental Standards and Regulations Enforcement Agency (Establishment) (NESREA) Act, 2007, captioned 'Functions of the Agency' and 'Powers of the Agency'; Section 7 (b) of the NESREA Act, which provides that NESREA shall enforce compliance with guidelines and legislations on sustainable management of the ecosystem, biodiversity conservation and the development of Nigeria's natural resources; Section $8(\mathrm{e})$ of the NESREA Act, which provides that NESREA is empowered to conduct field follow-up of compliance with set standards and take procedures prescribed by law against any violator; Environment Canada (Department of the Environment, Canada), 'Stantec: Sisson Project: 9.0: Environmental Impact Assessment (EIA) Report: Follow-Up and Monitoring [July Program' 2013] acee.gc.ca/050/documents_staticpost/63169/93967/Vol2/Sisson_EIA_July2013_Section_9-0_Followup_and_Monitoring_Program.pdf $>$ Accessed 7 February, 2020

${ }^{6}$ Section 5, defunct FEPA (Amendment) Decree (Decree No. 59 of 1992) and later-on FEPA Act, Cap F10 LFN 2004, captioned 'Functions of the Agency'; Section 7 of the NESREA Act, 2007, captioned 'Functions of the Agency'.

${ }^{7}$ Section 20, 1999 Constitution of the Federal Republic of Nigeria (CFRN) (as amended), captioned 'Environmental Objectives', of the federation; Section 7, NESREA Act, 2007, captioned 'Functions of the Agency'; Helios Towers Nig. Ltd v National Environmental Standards and Regulations Enforcement Agency (NESREA) \& Anor [2009/2010] Suit No. FHC/KD/CS/65/2009 and Appeal No. CA/K/123/2010.
} 
Pipelines Act, ${ }^{1}$ as well as town and country (national) planning systems. On this note, EIOs of MNRs, such as PRDOs projects, may be considered in the context of national planning, so as to regulate these operations in conformity with national planning laws and PPPs. ${ }^{2}$ Specifically concerning the Oil Pipelines Act and as regards petroleum pipeline projects, PI or CI takes place in the form of public objection hearings, during public objection hearing sessions organised by oil producing states of the Niger Delta region. ${ }^{3}$

Public objection hearings are usually organised for and on behalf of the Minister of Petroleum Resources, by Ministries of Land of the states in the oil-rich Delta region, where PRDOs are taking place. These hearings and development-planning verification sessions associated with land-use systems in Nigeria are statutorily provided for, in order to grant permits to survey the routes of pipelines in petroleum development projects, pipelines of the derivatives or components of crude petroleum and any other process of transportation connected with petroleum trade or operations in Nigeria. ${ }^{4}$ These hearings are open to the affected public, and sometimes include other concerned and/or interested members of the public and citizens of the country. The hearings constitute opportunities for those who are affected by, concerned with or interested in the subject matter of such hearings, to register and present their objections and substantiate them with relevant documentary or other forms of evidence. ${ }^{5}$ Essentially, public objection hearings in Nigeria constitute an attempt by the federal and affected state governments to ensure that proponents of petroleum development projects carried their petroleum pipeline and other related operations in compliance with the Oil Pipelines Act and other relevant laws, regulations, guidelines, standards and policies of the federation governing these operations. However, ironically these objection hearings are not being integrated into the EIA process of petroleum resources development projects, in a way that promotes comprehensive and integrated Environemtnal Assessment (EA) as well as environemntal democacy in the country.

Also, as a form of corporate voluntary scheme, oil and gas companies, especially MNOCs operating in the Niger Delta region, are increasingly designing and implementing peculiar in-house PI/CI strategies in the course of their oil and gas development projects in the region. Hence, Shell Petroleum Development Company Nigeria Limited (SPDC/Shell Nigeria) developed and published some in-house PI/CI procedural guidelines and standards to guide its stakeholder involvement processes in the course of its petroleum development projects in the oil producing communities of the Delta region. These are (i) Environmental Impact Assessment (EIA) Process: Stakeholders' Guide; ${ }^{7}$ (ii) Accompanying Guidelines for SPDC EIA Process: Stakeholders Identification and Involvement; ${ }^{8}$ (iii) Accompanying Guidelines for SPDC EIA Process: Scoping; ${ }^{9}$ (iv) Accompanying Guidelines for SPDC EIA Process: Data Collection; ${ }^{10}(\mathrm{v})$ Accompanying Guidelines for SPDC EIA Process: Report Review; ${ }^{11}$ and (vi) Accompanying Guidelines for SPDC EIA Process: Preparation and Implementation of Environmental Management Plan. ${ }^{12}$

Also, Nigeria NLNG Limited (NLNG), which holds out itself as a world-class LNG company, convenes quarterly CI with its primary host Bonny Kingdom's Community-based Environmental Organisation (CBO), known as the Bonny Environment Consultants' Committee (also called 'the Bonny Environment Consultants' Company' [BECC]). Aspects of the NLNG quarterly meetings with BECC often include representatives of government environmental regulatory organs such as those of the Federal Ministry of Environment (FMEnve), Rivers State Ministry of Environment and the Bonny Local Government Environmental Protection Committee (EPC). By and large, oil and gas industry in Nigeria may be described as the leader of EIA process and practice in the country, even as the global oil and gas industrial sector occupies a leadership status in the application of impact assessment (IA). ${ }^{13}$

\footnotetext{
${ }^{1}$ Oil Pipelines Act, 1958 (Cap 338 LFN 1990, now Cap 07, LFN 2004).

${ }^{2}$ A. L. Clark and C. J. Johnson, Mineral Resource Assessment for National Planning and Policy Formulation (Resource System Institute EastWest Centre 1988).

${ }^{3}$ E. T. Bristol-Alagbariya (2010 [n2]), 171-178; L. Atsegbua, 'The Development and Acquisition of Oil Licences and Leases in Nigeria' [1999] 23 (1) OPEC Review, 58

${ }^{4}$ Section 9 (1) 9 (1) of the Oil Pipelines Act, Cap 07 LFN 2004, captioned 'Notice of Objection'.

${ }^{5}$ Sections 6 (1), 8 (2), 9 (1) of the Oil Pipelines Act, 2004; Section 6 of the Oil Pipelines Act is captioned 'Notice before entry, damage, compensation, etc.'; Section 8 of the Oil Pipelines Act is headed 'Application for Licence and Notice thereof'; Section 9 of the Oil Pipelines Act is entitled 'Notice of Objection'.

${ }^{6}$ A. Gilpin (n32), 171.

${ }^{7}$ Document No. SPDC 2003-069, June 2003

${ }^{8}$ SPDC 2004-0002710, Vol. I, March 2004.

${ }^{9}$ SPDC 2004-0002711, Vol. II, March 2004

${ }^{10}$ SPDC 2004-0002712, Vol. III, March 2004

${ }^{11}$ SPDC 2004-0002713, Vol. IV, March 2004

12 SPDC 2004-0002714, Vol. V, March 2004

${ }^{13}$ Joint E \& P Forum and UNEP, Environmental Management in Oil and Gas Exploration and Production: An Overview of Issues and Management Approaches (E \& P Forum/UNEP 1997); International Association for Impact Assessment (IAIA), 'Final Program: $24^{\text {th }}$ Annual Conference of the International Association for Impact Assessment, 24 - 30 April 2004, Vancouver Canada, Whose Business Is It? Impact Assessment for Industrial Development', 8 and $10<\mathrm{https} / /$ conferences.iaia.org/2004/pdf/04\%20finalpro-English.pdf $>$ Accessed 7 February, 2020 .
} 
However, the foregoing forms of environmental democracy, which take place as PI/CI during PRDOs in the Nigerian Delta region are often basically consultative. These forms of environmental democracy are essentially not interactive and as such may not be categorised as interactive forms of PI/CI known as PP/Community Participation. Worse still, whereas private sector project proponents, such as oil and gas companies, embark on and are subjected to PI/CI processes during the implementation of their petroleum development projects, public sector (i.e., government) development project proponents at various levels of government in Nigeria, namely federal and states levels of government and local government levels, rarely comply with the EIA Act of the country. In fact, cases abound where public sector development project proponents do not disclose their project proposals to the EIA Department of the FMEnve, so as to enable the Department to subject their proposals to the EIA process, as stipulated by the EIA Act. Therefore, public sector development project proponents in Nigeria hardly embark on PI/CI during the implementation of their infrastructural and other physical development projects. ${ }^{1}$

Furthermore, relatively the same as PI/CI, the prevailing degree of environmental justice in Nigeria (be it in the form of administrative justice or judicial justice) is weak. By and large, as evidenced by certain judicial decisions, ${ }^{2}$ access to environmental justice is weak in Nigeria, and this may be so as compared with the state of affairs in other resources-rich developing countries. Altogether, it may be noted that access to justice in the EIA processes of EIOs in resources-rich developing countries is weaker than what is expressed in Principle 10 of the Rio Declaration on Environment and Development, 1992, and elaborated in the Aarhus Convention, 1998.

Besides, it is pertinent to state that EIA in the course of petroleum resources development projects in Nigeria is bedevilled by lack of SD-Oriented Impact-benefits such as Sustainable Community Development (SCD) programmes and projects. Generally, social investments of oil and gas companies, especially MNOCs, in the Niger Delta region are based on Memoranda of Understanding (MoUs) rather than multi-stakeholders Impact-Benefit Agreements (IBAs) ${ }^{3}$ and other forms of SD-Oriented Good Neighbour Agreements (GNAs) such as the Canadian Whitehorse Mining Initiative (WMI), ${ }^{4}$ Socio-economic and Cultural Heritage Schemes, Community Development Trusts and Heritage Funds like the Alaska Permanent Fund ${ }^{5}$ and other forms of SCD and Sustainable Community Empowerment (SCE) Agreements. It is crucial for multi-stakeholders SD-Oriented GNAs to have provisions for various forms of SCD and SCE opportunities. These opportunities should include projects' lifecycle CD and Community support schemes such as full-scale pensionable employment, other forms of human capacitydevelopment, healthcare and small and medium scale enterprises (SMEs) support programmes in the oil producing communities.

So far, the predominance of MoUs between the oil-rich communities and oil and gas companies, especially MNOCs, in the Niger Delta region, is causing misunderstanding, industrial disharmony and crises in the communities of the region and other oil producing areas of Nigeria.

Another problem associated with the prevailing EIA process in Nigeria is that it is plagued by the lack of or ineffective project-life (full or complete project lifecycle) IA. By and large, EIA in Nigeria is plagued by nonexistence of formal Strategic Environmental Assessment (SEA) of PPPs in the country, which has the potential to boost greater environmental governance, and greater wellbeing of the environment, people and communities of the oil-rich Niger Delta region in the course of PRDOs in the region. ${ }^{6}$

Due to the foregoing and other problems, challenges and adverse consequences of PRDOs in the oil-rich Delta region and other oil producing areas of Nigeria, the environment in the Delta region is increasingly being terribly degraded, ecologically devastated, with despoiled eco-system and ecosystem services. ${ }^{7}$ Also, the oil-rich Delta region is witnessing abuses and violations of the human rights of its citizens, increasing poverty, political and socio-economic marginalisation and underdevelopment in the course of over six decades of PRDOs in the oil producing communities of the region. ${ }^{8}$ Thus, from the $1990 \mathrm{~s}$, the oil-rich minority ethnic Delta region has been witnessing community crises, violent conflicts, near-civil war unrests and self-determination struggles, aggravated

\footnotetext{
${ }^{1}$ U. Etemire (n5), 59-60; Federal Government of Nigeria, Draft Final Report E2283, captioned 'Infrastructure Concession and Regulatory Commission Environmental and Social Management Framework for Nigeria Public Private Partnership Program' (November 3, 2009), 50.

${ }^{2}$ Oronto Douglas $v$ The Shell Petroleum Development Company of Nigeria Limited \& 4 Ors [1999] 2 NWLR, Pt. 591, 466-467; C/f Jonah Gbemre v The Shell Petroleum Development Company Nigeria Ltd \& 2 Ors [2005] FHC/B/CS/53/05); K. S. A. Ebeku, 'Constitutional Right to a Healthy Environment and Human Rights Approaches to Environmental Protection in Nigeria: Gbemre v. Shell Revisited' [2007] 16 (3) Review of European Community and International Environmental Law (RECIEL), 312-320.

${ }^{3}$ Á. J. 'Wright, Impact and Benefit Agreements: The Role of Negotiated Agreements in the Creation of Collaborative Planning in Resource Development' $<$ https://ccednet-rcdec.ca/en/toolbox/impact-and-benefit-agreements-role-negotiated-agreements $>$ Accessed 7 February, 2020.

${ }^{4}$ Natural Resources Canada, 'Whitehorse Mining Initiative' <http://www.nrcan.gc.ca/mining-materials/policy/government-canada/8698> Accessed 7 February, 2020.

${ }^{5}$ Alaska Permanent Fund Corporation (APFC), 'Investing for Alaska Investing for the Long Run: Our Mandate' < https://apfc.org/> Accessed 7 February, 2020; D. Peel and N. Bailey, Celebrating Community Involvement (Development Trusts Association 2003), especially 3-15.

${ }^{6}$ E. T. Bristol-Alagbariya (2013 [n20]), xxxiii, xxxix-xl, xliii-xlvii, 35-36, 67-68, 71-72, 73-96 and 276-285; E. T. Bristol-Alagbariya (2010 [n2]), 140-141, 144 -146, 326-327 and 330; B. Sadler et al (eds), Handbook of Strategic Environmental Assessment (Earthscan 2011).

${ }^{7}$ UN Environment Programme (UNEP), Environmental Assessment of Ogoniland (UNEP 2011); E. T. Bristol-Alagbariya, Petroleum Development \& the Environment in Rivers State Nigeria: Fallouts of the UNEP Report on Ogoniland, Environmental Regulatory Standards \& Sustainable Development Laws \& Practices (LAP LAMBERT Academic Publishing 2018) 47-54.

${ }^{8}$ V. Egwemi et al (eds) (n63); S. Azaike (n63); R. T. Suberu (2003 [n63]); R. T. Suberu (2001 [n63]).
} 
by militant youth restiveness, due to negative consequences of the RDOs in the communities of the region. ${ }^{1}$ There are prevalence of unsustainable PRDOs as well as unsustainable CD, and weak environmental democracy. Thus, PRDOs governed by benchmarked international standards and practices regulating EIOs, are possibly the solution to the myriads of negative consequences of PRDOs in the oil-rich communities of the minority ethnic Delta region and other oil producing areas of Nigeria and the resource curse plaguing the country.

Consequently, improved and genuine participation of citizens and citizen-groups of the oil-rich Delta region, secured in the course of lifecycle EIA and SEA, along with Social Licence to Operate (SLO) ${ }^{2}$ granted by the oil producing communities in the course of PRDOs, have the potential of ensuring greater protection of the environment and all-embracing Community Empowerment, towards SCD, industrial peace and harmony and above all, SPRDOs in the Delta region. ${ }^{3}$ Lifecycle EIA and SEA, coupled with SLO (i.e., legitimacy) granted by the oil producing communities in the course of PRDOs, have the potential to boost greater human wellbeing, vitality of natural resources and overall nature, towards all-embracing SD in the Delta region. ${ }^{4}$

So far, among other related issues, the discussion under this sub-heading has examined the weak nature of environmental democracy in the course of PRDOs, as aspects of EIOs, in the oil-rich Nigerian Delta region in relation to the adverse consequences of the RDOs, which contributed to generate the crises-riven situation of the region hindering SD of the RDOs in the oil-rich communities of the Delta region. It may be pertinent at this juncture to deliberate a little on SD.

The report of the World Commission on Environment and Development (WCED) popularly known as the Brundtland's Commission report, entitled Our Common Future defines SD as the development which meets the needs of the present without compromising the ability of future generations to meet their own needs. ${ }^{5}$ The Earth Charter Initiative (ECI) states that SD expands our vision towards ethical or greater ethical principles and practices. This Charter is an international declaration of fundamental values and principles, having its constituent global movement of organisations and individuals that embrace the declaration for building vision, attitude, knowledge, wisdom, skills and values needed to achieve a more just, sustainable and peaceful world. ${ }^{6}$

Among others, SD has aspects (components, pillars or spheres), principles, indicators, strategies and SDoriented initiatives. The aspects of SD are basically its economic, social, environment and governance spheres, as well as its ecological and cultural components. Among these, the governance aspect of SD, namely good governance (GG), is very significant, key and most important. Thus, GG and SD are to be indivisible, as SD cannot be achieved without GG, as its foremost, greatest and most significant enabler. ${ }^{7}$

Regarding principles, SD has the following principles, namely the precautionary principle, pollution prevention pays principle $\left(3 \mathrm{p}^{+}\right)$, polluter pays principle (PoPP), user pays principle (UPP), principle of intragenerational equity, principle of inter-generational equity, and the principle of participation (environmental democracy: about which this study is specifically concerned and thus focused upon). These principles convey the links between development processes, environmental factors, and human and other resources of nature. ${ }^{8}$

Also, SD has its indicators known as SD Indicators (SDIs). An indicator may be described as a device that shows what a situation is like, such as a value, or a change in level, speed, etcetera, and thus demonstrates the

${ }^{1}$ F. O. Adeola, 'Environmental Injustice and Human Rights Abuse: The States, MNCs, and Repression of Minority Groups in the World System' [2001] 8 (1) Human Ecology Review, 39-59; B. Manby, The Price of Oil: Corporate Responsibility and Human Rights Violations in Nigeria's Oil Producing Communities (Human Rights Watch 1999); J. G. Frynas and S. Pegg (eds), Transnational Corporations and Human Rights (Palgrave Macmillan 2003); J. G. Frynas, 'The False Developmental Promise of Corporate Social Responsibility: Evidence from Multinational Oil Companies', [2005] 81 (3) International Affairs, 581-598.

2 J. Morrison, The Social Licence: How to Keep Your Organization Legitimate (Palgrave Macmillan 2014); L. Black, The Social Licence to Operate: Your Management Framework for Complex Times (Routledge 2017); J. Morrison, International Business Challenges in a Changing World (Springer Nature 2019); K. K. Aaron, Corporate Social Responsibility Performance in the Niger Delta: Beyond Two Constitutive Orthodoxies' [2011] 21 (6) Development in Practice, 779-789; E. Wilson, 'What is Social Licence to Operate? Local Perceptions of Oil and Gas Projects in Russia's Komi Republic and Sakhalm Island'[2016] The Extractive Industries and Society, 3 (1) 73-81; K. Elendu, 'Social Licence to Operate: A Solution to Community Crises with Oil Companies'<https:/medium.com/@kingsonelendu/social-licence-to-operatea-solution-for-community-crises-with-oil-companies-b9b3b669e8ab> Accessed 7 February, 2020; KPMG, 'Opportunities to Strengthen Social Licence for Oil and Gas Companies'<https://home.kpmg/au/en/home/insights/2019/06/social-licence-for-oil-and-gas.html $>$ Accessed 7 February, 2020; J. Bairstow, Oil and Gas Industry's 'Social Licence to Operate under Serious Threat' $<$ https://www.energylivenews.com/2020/01/17/oil-and-gas-industrys-social-licence-to-operate-under-serious-threat/> Accessed 7 February, 2020.

${ }^{3}$ L. Barrera-Hernandez et al (eds), Sharing the Costs and Benefits of Energy and Resources Activity: Legal Change and Impact on Communities (Oxford University Press 2016)

${ }^{4}$ E. T. Bristol-Alagbariya (2018 [n103]), 47-54; B. Sadler et al (eds) (n102); Goals 3 and, UN SDGs, captioned 'Good Health and Wellbeing'; Goals 7 and 12, UN SDGs, respectively captioned 'Affordable and Clean Energy' and ''Responsible Consumption and Production'.

${ }^{5}$ The World Commission on Environment and Development (WCED), Our Common Future (Oxford University Press 1987), 8, 40 and 43.

${ }^{6}$ Homepage of the Earth Charter Initiative (n22); The Earth Charter, 'Earth Charter Education' <https://earthcharter.org $>$ Accessed 7 February, 2020.

${ }^{7}$ WCED (n109), x-23, particularly 9; K. Annan, 'International Conference on Governance for Sustainable Growth and Equity', New York, 28-30 July, 1997 <http://www.pogar.org/publications/other/undp/governance/annan-address-e.pdf> Accessed 28 January, 2019; G. Ayre and R. Callway (eds), Governance for Sustainable Development: A Foundation for the Future (Earthscan 2005); H. Clark, The Importance of Governance for Sustainable Development (The Institute of Southeast Asian Studies [ISEAS] Publishing 2012).

${ }^{8}$ FEPA, National Policy on the Environment (FEPA 1999) 1; Principle 1, Rio Declaration on Environment and Development, 1992. 
existence of the given situation or clarifies that the situation is true or otherwise. ${ }^{1}$ It is a measurement tool, such as a gauge or meter, guide or standard, sign or signal, which indicates the state, level or degree of something. Based on certain indices, indicators measure trends towards SD, so as to enable countries, nations, organisations and peoples around the world, to measure, monitor, evaluate and thereby effectively streamline their efforts towards SD. ${ }^{2}$ There are several SDIs, which are directly or indirectly associated with human wellbeing and they are all targeted towards achieving the wellbeing of humanity, the environment and overall nature on Planet Earth. ${ }^{3}$

The UN Agenda 21 is also important and inevitable in the context of worldwide efforts towards SD. Agenda 21 has already been described in this study as one of the outcome documents of UN Rio de Janeiro Earth Summit, 1992, which is designed to guide the twin relationship of the environment and development, and thus future approaches to development towards SD. It is a global plan of action to promote and facilitate SD. It is a wideranging blueprint and most comprehensive plan outlining necessary actions aimed at achieving SD globally, ranging through local, national and international levels. ${ }^{4}$ Agenda 21 may also be described as a 'greenprint' for global partnership, which aims at a high quality environment and a healthy economy for all peoples on Planet Earth. It addresses critical issues confronting the entire world, such as continuing damage to ecosystems; worsening poverty, hunger and ill health; increasing world population and illiteracy. It is comprised of 40 Chapters, which identify each challenge and proposes simple and realistic solutions towards SD. Thus, from the UN Agenda 21 , member-states of the UN were to design and develop and did, in fact, design and develop their respective Agenda 21, as their separate and peculiar instruments towards SD, in their respective jurisdictions or localities. ${ }^{5}$

So far, using economic tools as one of the means to achieve SD, there is the Green Economy Initiative that is designed in the UN system as a contemporary dominant economic model, which has the potential to promote SD and poverty reduction, towards accelerating human wellbeing, environmental protection and preservation of ecology and ecosystems. ${ }^{6}$

Regarding Goals (SD Goals), there has been a transition from the Millennium Development Goals (MDGs) to the SD Goals (SDGs) in the UN system. Efforts of the entire global community to achieve SD commenced from the historic inspirational target (known as the UNMDGs), to the extant monumental aspirational target (known as the UNSDGs). In the process, by its Resolution 53/202 of 17 December, 1998, the UN General Assembly (UNGA), decided to designate its $55^{\text {th }}$ Session, 'The Millennium Assembly of the UN', and to convene, as an integral part of the Millennium Assembly, a Millennium Summit of the UN (UNMS), ${ }^{7}$ which took place from Wednesday, 6 September, to Friday, 8 September, 2000, at UN Headquarters, in New York. The main document that was unanimously adopted by the UNMS was the UN Millennium Declaration, which conveys a statement of values, principles and objectives comprising an international agenda for the $21^{\text {st }}$ Century. To commit countries and people of the world, the Summit framed a series of Eight time-bound Goals, known as the MDGs, which are to be achieved by the target year, $2015 .^{8}$ As nations and peoples of the world, particularly those of developing countries, were unable to achieve the MDGs by the target year (2015), the global community, under the auspices of the UN, introduced the SD Goals (SDGs), which are Seventeen in number. These Seventeen UNSDGs are designed to end poverty, protect the planet, and ensure peace and prosperity for all as part of a new SD agenda. ${ }^{9}$ The SDGs,

${ }^{1}$ Cambridge Dictionary, 'Indictor' <https://dictionary.cambridge.org/dictionary/english/indicator $>$ Accessed 7 February, 2020.

2 The UN Department on Economic and Social Affairs (UNDESA), Indicators of Sustainable Development: Guidelines and Methodologies (UN 2007); UN Sustainable Development Knowledge Platform, 'Indicators in the Transforming Our World - The 2030 Agenda for Sustainable Development' $<$ https://sustainabledevelopment.un.org/topics/indicators $>$ Accessed 7 February, 2020; P. Gennari, 'Key Indicators of Sustainable Development'<https://www.mofa.go.jp/policy/economy/eismap/k seminar/Round-2-3.pdf> Accessed 28 January, 2019; The Department of Environment, Food and Rural Affairs (DEFRA) UK, Sustainable Development Indicators July 2013 (The National Archives/Sustainable Development Statistics 2013); S. Bell and S. Morse, Sustainability Indicators: Measuring the Immeasurable? (Earthscan 2008).

${ }^{3}$ Nature Geoscience, 'Sustainability on Earth'<https://www.nature.com/collections/mzyhgncgsm $>$ Accessed 7 February, 2020.

4 UN SDGs Knowledge Platform, Division of SDGs, Department of Economic and Social Affairs (DESA), 'Agenda 21' $<$ https://sustainabledevelopment.un.org/outcomedocuments/agenda21> Accessed 7 February, 2020.

${ }^{5}$ UN SDGs Knowledge Platform, Division of SDGs, DESA, 'United Nations Conference on Environment and Development Rio de Janeiro Brazil, 3 to 14 June 1992 Agenda 21'<https://sustainabledevelopment.un.org/content/documents/Agenda21.pdf $>$ Accessed 7 February, 2020; FEPA, Nigeria's National Agenda 21 (FEPA 1999).

${ }^{6}$ Paragraph 102, 'Focused Political Outcome Document of the UNCSD (Rio+20), 2012, 'The Future We Want - Outcome Document', captioned 'Green Bridge Partnership Programme' towards SD; W. L. Filho et al (eds), Sustainable Economic Development: Green Economy and Green Growth (Springer International Publishing 2017); J, A. Puppim de Oliveira (ed), Green Economy and Good Governance for Sustainable Development: Opportunities, Promises and Concerns (UN University Press 2012); W. Hynes and S. Wang, Green Growth and Developing Countries: A Summary for Policy Makers (The Organisation for Economic Co-operation and Development [OECD] 2012); UN System Chief Executives Board for Coordination, 'Green Economy Initiative' $<$ https://www.unsystem.org/content/green-economy-initiativegei $>$ Accessed 7 February, 2020 UNEP, 'Green Industrial Policy: Concept, Policies, Country Experiences'<https://www.unenvironment.org/resources/report/green-industrial-policy-concept-policies-country-experiences $>$ Accessed 7 February, 2020.

UN, 'Conferences, Meetings and Events: Millennium Summit $(6 \quad-\quad 8 \quad$ September 2000 )' $<$ https://www.un.org/en/events/pastevents/millennium summit.shtml $>$ Accessed 7 February, 2020.

${ }^{8} \mathrm{UN}$, 'Millennium Development Goals and Beyond 2015: News on Millennium Development Goals' < https://www.un.org/millenniumgoals/> Accessed 7 February, 2020.

${ }^{9}$ UNGA, 'Resolution adopted by the General Assembly on 25 September 2015 70/1: Transforming our world: the 2030 Agenda for Sustainable 
described as 'Global Goals', constitute a blueprint to achieve a better and more sustainable future for all. ${ }^{1}$ The Goals address global challenges confronting humanity, countries and society at large, such as poverty, inequality, climate change, environmental degradation, peace and justice. These Seventeen Goals are interconnected, and are meant to be achieved by the target year (2030), in order not to leave any country or people behind (without achieving them by the afore-mentioned target year). ${ }^{2}$ Each of the Seventeen SDGs has specific targets to be achieved over a fifteen year period (from 2015), and all sectors of society, namely government, the private sector, civil society and individuals, ought to accomplish their roles for these Goals to be achieved. ${ }^{3}$

Considering the prerequisites towards a more just, sustainable and peaceful sovereign states around the world and as well as more just, sustainable and peaceful global community, the role of good public sector governance, namely good political leadership (good governance [GG]), in global states cannot be overemphasised. No doubt, there is an imperative and inevitable urgent need for GG, to pilot the affairs of resources-rich developing countries, being plagued by the recourse curse, towards SD. ${ }^{4}$

\subsection{Sustainable Petroleum Resources Development Operations (SPRDOs) and Sustainable Community Development (SCD) in the Oil-rich Niger Delta Region}

While considering sustainable petroleum resources development operations (SPRDOs), it is significant to note that petroleum resources are finite (i.e., non-renewable energy and natural) resources and development operations of these resources impact negatively, as well as undermine the wellbeing of humans and other resources of nature, such as the environment, ecology, ecosystems and ecosystem services in the oil producing communities of the Delta region. Consequently, SD of petroleum resources in the oil-rich Delta region and other oil-producing areas of Nigeria is difficult to achieve. However, there could be peaceful SPRDOs in Nigeria's oil producing areas based on appropriate government regulation of these development operations and on benchmarked international standards and practices regulating petroleum and other EIOs, such as good oil-field standards, values and practices, improved environmental and social responsibilities of the oil companies, as well as good environmental governance (GEG) by appropriate government regulatory agencies in the course of PRDOs in the oil producing areas of the country.

Accordingly, given that societies and thus communities cannot survive indefinitely, as the idea of sustainable societies does not mean that any human society can survive indefinitely. It rather refers to a society, and thus a community, that is organised and thrives by utilising the resources of nature in a sustainable form or manner, such that it has the potential of surviving for a long period, within a foreseeable human context, namely in the context of human civilisation within Planet Earth. ${ }^{5}$

Consequently, SD is a path to or towards sustainability and not infinity. In other words, SD only moves communities, countries and the entire global society, toward the sustainability quadrant, given that unbalanced ecological base occasioned by developmental PPPs in human societies is threatening the very survival of communities, countries and the entire global society, in the ongoing era of human civilisation. ${ }^{6}$

\section{Conclusion}

This study has attempted to examine the concept, principle, law and developmental practice of environmental democracy towards SD in resources-rich communities of developing countries, in the context and prevailing

Development' <https://www.un.org/ga/search/view_doc.asp?symbol=A/RES/70/1\&Lang=E> Accessed 7 February, 2020; UN, 'A/RES/70/1 Transforming our world: the 2030 Agenda for Sustainable Development 21 Oct 2015' $<$ https://sustainabledevelopment.un.org/index.php?page=view\&type=111\&nr=8496\&menu=35> Accessed 7 February, 2020; ..... UNDP, UN SDGs $<$ https://www.undp.org/content/undp/en/home/sustainable-development-goals.html $>$ Accessed 7 February, 2020.

${ }^{1}$ UNDP, UN SDGs (n121)

${ }^{2}$ UN, 'Sustainable Development Goals: About the Sustainable Development Goals' $<$ https://www.un.org/sustainabledevelopment/sustainabledevelopment-goals/> Accessed 7 February, 2020.

${ }^{3}$ Ibid.

${ }^{4}$ WCED (n109), x-23, particularly 9; E. T. Bristol-Alagbariya (2013 [n103]), xxxvii-xxxviii, 46-49 and 272-393; E. T. Bristol-Alagbariya (2010 [n2]), 75-82 and 329-337; R. Hannesson, Investing for Sustainability: The Management of Mineral Wealth (Kluwer 2001); K. Ginther et al (eds), Sustainable Development and Good Governance (Martinus Nijhoff Publishers 1995); G. Ayre and R. Callway (eds) (n111); H. Clark (n111).

${ }^{5}$ D. Doherty D. and M. de Geus (eds), Democracy and Green Political Thought: Sustainability, Rights and Citizenship (Routledge/ECPR Studies in European Political Science 1996), 173-174; A. Gare, 'From 'Sustainable Development' to 'Ecological Civilization': Winning the War for Survival' [2017] 13 (3) Cosmos and History: The Journal of Natural and Social Philosophy, 130-153; W. E. Kelly et al, Engineering for Sustainable Communities Principles and Practices (American Society of Civil Engineers 2017); R. Dodds and R. Venables (eds), Engineering for Sustainable Development: Guiding Principles (The Royal Academy of Engineering 2002); J. Lucena et al, 'Engineering and Sustainable Community Development [2010] 5 (1) Synthesis Lectures on Engineers, Technology, and Society, 1-230; E. T. Bristol-Alagbariya, 'Concepts and Theories on the Legal Principle of Permanent Sovereignty over Natural Wealth and Resources in Relation to Petroleum Development in Nigeria' [2019] 4 (2) University of Port Harcourt Journal of Private Law, 189-212.

${ }^{6}$ D. Doherty and M. de Geus (eds), Democracy and Green Political Thought: Sustainability, Rights and Citizenship (Routledge/ECPR Studies in European Political Science 1996), 173-174; J. Manno and A. Fix, 'Environmental Sustainability and Sustainable Development' $<$ https://oxfordre.com/internationalstudies/view/10.1093/acrefore/9780190846626.001.0001/acrefore-9780190846626-e-169?print=pdf $>$ Accessed 7 February, 2020. 
circumstances of petroleum EIOs in the oil producing communities of the Nigerian Delta region. It discussed environmental democracy as an aspect of PP, and community participation/CI is an aspect of PP.

The study considered the importance of environmental democracy, stipulated in Principle 10 of Rio Declaration on Environment and Development, 1992 and elaborated in the Aarhus Convention, 1998, in the course of petroleum EIOs in the oil-rich minority ethnic Niger Delta region. It stressed that the region is being politically and socio-economically marginalised in the course of nation-building in Nigeria, such that it is poor and underdeveloped, although it is enormously endowed with petroleum resources.

The study also examined the role of environmental democracy towards sustainable petroleum resources development operations (SPRDOs) as well as sustainable community development (SCD) in the oil-rich communities of the Niger Delta region, considered as outstanding resources-rich communities of resources-rich developing countries, suffering from the resource-curse. It is on this note that the above-stated two areas of SD (namely sustainable PRDOs in Nigeria and SCD in the oil-rich Nigerian Delta region) were basically and essentially focused on.

The study demonstrates that the most visible, enriched and celebrated aspect of environmental democracy in the course of PRDOs in the oil-rich Nigerian Delta region is that associated with EIA of the resources development projects in the oil producing communities of the region. Paradoxically, even in the context of the prevailing EIA, environmental democracy is basically reduced to mere consultation rather than interactive community involvement (CI), which connotes community engagement (i.e., active community participation). There is therefore a need for improvement of corporate environmental and social responsibilities in the oil producing communities of the Delta region, and a greater need for government social responsibility (GSR), embedded in GG, to vitalise, promote and achieve GEG, and the wellbeing of the environment and humanity, towards addressing the resource curse inflicted on Nigeria in the course of the development of the country's abundant petroleum resources being extracted in the oil-rich communities of the Delta region.

So far, the study has demonstrated the significance of genuine environmental democracy, an aspect of interactive public engagement (PP). Among its other significant features and relevance to society, PP, which community participation is an aspect of, promotes and enhances good decisions, and more often, ensures that decisions are sound, fair, better and thus long-lasting. Participation helps to reconcile conflicting interest among stakeholders involved in decision-making; it protects public interest; on the basis and strength of PP, stakeholders abide by their decisions and implement such decisions in an enduring manner; participation ensures that decisions affecting land, natural resource as well as MNRs, such as oil and gas and other mining and mineral resources, adequately and equitably address the aspirations, concerns and interests of affected citizens; PP promotes and strengthens GEG, overall GG, and SD, towards greater human wellbeing and the wellbeing of overall nature and the entire Planet Earth; PP is thus a stimulant of environmentally-sound, ecologically-centred and socioeconomically equitable SD.

In concluding also, we assert that Nigeria, as typical example of a developing country plagued by the resource curse, is far from achieving SD. The road to PRDOs in Nigeria is certainly rough and long, considering ongoing disruptions of development operations of these resources in the oil-rich Delta region. These disruptions are taking place due to militant youth restiveness, oil-bunkering and illegal refining activities, as well as the inability of oil and gas companies and government regulatory agencies to properly manage and regulate the resources development operations in the oil-rich communities of the Delta region, in compliance with benchmarked international guidelines, standards and practices governing EIOs. Worse still, the road to SCD is more longer and thus more elusive or utopian to achieve, due, among other reasons, to the gravity of environmental degradation, ecological devastation and ecosystem despoliation occasioned in oil-rich communities of the Delta region as well as the socio-economic and political neglect and marginalisation of these communities taking place in the course of nation-building in Nigeria.

Sustainable petroleum resources extractive industrial development operations as well as SCD in the oil-rich Nigerian Delta region are untenable, except and unless GG is enthroned in the country, as GSR, embedded in GG, has the potential to institutionalise good oilfield practices, an improvement of the quality of the environment and environmental justice, through GEG, as well as social equity, in the course of PRDOs in the Delta region. The enthronement of GG and existence of GEG would vitalise, promote and achieve overall wellbeing of the environment in Nigeria, towards SPRDOs in the Delta region. GSR, embedded in GG, also has the potential to support and encourage SCD and to boost human wellbeing in the Delta region and other regions of Nigeria. Put otherwise, SPRDOs and SCD in the oil-rich Niger Delta region can only be achieved by virtue of the existence or instrumentality of good, responsible, transparent and accountable government in Nigeria. GG will pilot Nigeria away from its prevailing resource curse, as the desired governance has the potential to promote, generate and energise the improvement of corporate environmental and social responsibilities in the oil-rich Delta region as well as the capacity and strength to boost the realisation and sustenance of social responsibilities of civil society groups, such as community social responsibility (SRC), towards SD in the country. Nevertheless, it should be noted that no community or society can survive indefinitely, as the idea of sustainable societies does not mean that 
any human society can survive indefinitely beyond the sustainability of human civilisation within Planet Earth.

We therefore join in echoing that there is a crucial, urgent and inevitable need for good public sector governance (GG) in Nigeria. Accordingly, we recommend that genuine environmental democracy (stipulated in Principle 10 of Rio Declaration on Environment and Development, 1992, elaborated in the Aarhus Convention, 1998, cemented in the UN Brisbane Declaration on Community Engagement, 2005, and being profoundly canvassed by the IAIA and IAP2) should be practised in Nigeria to foster SPRDOs and SCD in the Delta region, so as to achieve greater human wellbeing, environmentally-sound, ecologically-centred and socio-economically equitable SD in the country, towards the wellbeing of overall nature and Planet Earth.

\section{References}

Aaron K. K., Corporate Social Responsibility Performance in the Niger Delta: Beyond Two Constitutive Orthodoxies' [2011] 21 (6) Development in Practice, 779-789.

Adangor Z., Federalism and Natural Resource Governance in Nigeria: An Agenda for Constitutional Reform (Sibon Books 2015).

Adeola F. O., 'Environmental Injustice and Human Rights Abuse: The States, MNCs and Repression of Minority Groups in the World System' [2001] 8 (1) Human Ecology Review, 39-59.

Ascher W., Why Governments Waste Natural Resources: Policy Failures in Developing Countries (John Hopkins University Press 1999).

Atsegbua L., 'The Development and Acquisition of Oil Licences and Leases in Nigeria' [1999] 23 (1) OPEC Review, 58.

Auty R. M., Sustaining Development in Mineral Economies: The Resource Curse Thesis (Routledge 1993).

Auty R. M. and Furlonge H., The Rent Curse: Natural Resources, Policy Choice, and Economic Development (Oxford University Press 2019).

Awoyemi O., The Impact of Oil Pollution on the Environment of the Oil Producing Communities of Nigeria: A Critical Analysis of the Statutory and Regulatory Provisions in Nigeria (Independent Law Publishing 2014).

Ayre G. and Callway R. (eds), Governance for Sustainable Development: A Foundation for the Future (Earthscan 2005).

Azaike S., Inequities in Nigerian Politics (Treasure Communications Resource 2003).

Bannon I. and Collier P. (eds), Natural Resources and Violent Conflict: Options and Actions (The World Bank 2003).

Barrera-Hernandez L., Barton B., Godden L., Lucas A., and Ronne A. (eds), Sharing the Costs and Benefits of Energy and Resources Activity: Legal Change and Impact on Communities (Oxford University Press 2016).

Barrie A. M., Dilemma of A Nation: Sierra Leone Blood Diamonds (A. M. Barrie Press Multi Services 2012).

Barrow C., Environmental Management for Sustainable Development (Routledge 2006).

Bassey N., Oil Politics: Echoes of Ecological Wars (Daraja Press 2016).

Bastida E., Walde T. and Warden-Fernandez J., (eds), International and Comparative Mineral Law and Policy: Trends and Prospects (Kluwer Law International 2005), 265-267 and 278-279.

Beierle T. C. and Cayford J., Democracy in Practice: Public Participation in Environmental Decisions (Resources for the Future 2002) 1-33.

Bell S. and Morse S., Sustainability Indicators: Measuring the Immeasurable? (Earthscan 2008).

Black L., The Social Licence to Operate: Your Management Framework for Complex Times (Routledge 2017)

Boughton G. S., Black Gold - Black Scorpion: Biafra Remembered (GB Publishing.org 2015).

Bristol-Alagbariya E. T., 'Concepts, Theories and the Legal Principle of Permanent Sovereignty over Natural Wealth and Resources in Relation to Petroleum Development in Nigeria'. [2019] 4 (2) University of Port Harcourt Journal of Private Law, 189, 195-199 and 212.

Bristol-Alagbariya E. T., Governance Towards Sustainable Development in Nigeria: The Role of Strategic Assessment of Decisions \& Actions (Centre for Energy, Petroleum \& Mineral Law \& Policy [CEPMLP]/Dundee University Press [DUP] 2013) particularly xxxii-xxxiii, xxxv-xxxix - xl, xliii-xlvii, 768, 71-96 and 265-293.

Bristol-Alagbariya E. T., Participation in Petroleum Development: Towards Sustainable Community Development in the Niger Delta (CEPMLP/DUP 2010) 18-19, 20, 24-26, 28-29 , 31, 33, 35-36, 40-41, 43, 45, 75-101, 140-141, $144-151,156-170-178$ and 325-337.

Bristol-Alagbariya E. T., Petroleum Development \& the Environment in Rivers State Nigeria: Fallouts of the UNEP Report on Ogoniland, Environmental Regulatory Standards \& Sustainable Development Laws \& Practices (LAP LAMBERT Academic Publishing 2018) 47-54.

Brown I. and Marsden C. T., Regulating Code: Good Governance and Better Regulation in the Information Age (The Massachusetts Institute of Technology [MIT] Press 2013).

Callahan K., 'Participation: Models and Methods' [2007] 30 (11) Journal of Public Administration, 1179 -1196. Cameron P. D. and Michael M. C. Oil, Gas, and Mining: A Sourcebookfor Understanding the Extractive Industries 
(World Bank Group 2017).

Campbell G., Blood Diamonds: Tracing the Deadly Path of the World's Most Precious Stones (Westview Press 2002).

Clark H., The Importance of Governance for Sustainable Development (The Institute of Southeast Asian Studies [ISEAS] Publishing 2012).

Clark A. L. and Johnson C. J., Mineral Resource Assessment for National Planning and Policy Formulation (Resource System Institute East-West Centre 1988).

Collier P., The Bottom Billion: Why the Poorest Countries Are Failing and What Can Be Done About It (Oxford University Press 2007).

Cook B. and Kothari U. (eds), Participation: The New Tyranny? (Zed Books 2004).

Corcoran P. B. (ed), The Earth Charter in Action: Toward a Sustainable (KIT Publishers 2006).

Creighton J. L., The Public Participation Handbook: Making Better Decisions through Citizen Involvement, (Jossy-Bass 2005), especially 1.

Dalal-Clayton B. and Sadler B., Strategic Environmental Assessment: A Sourcebook and Reference Guide to International Experience (Earthscan 2005).

Department of Environment, Food and Rural Affairs (DEFRA) UK, Sustainable Development Indicators July 2013 (The National Archives/Sustainable Development Statistics 2013).

DEFRA UK, Sustainable Development Indicators in Your Pocket: An Update of the UK Government Strategy Indicators (Crown 2009).

Department of Petroleum Resources (DPR), Environmental Guidelines and Standards for the Petroleum Industry in Nigeria (EGASPIN) (DPR 1991/2002 [Revised 2002]).

Dodds R. and Venables R. (eds), Engineering for Sustainable Development: Guiding Principles (The Royal Academy of Engineering 2002).

Doherty D. and de Geus M. (eds), Democracy and Green Political Thought: Sustainability, Rights and Citizenship (Routledge/ECPR Studies in European Political Science 1996), particularly 173-174.

Douglas O. and Okonta I., Where Vultures Feast: Shell, Human Rights, and Oil in the Niger Delta (Sierra Club 2001).

Oronto Douglas v The Shell Petroleum Development Company of Nigeria Limited \& 4 Ors [1999] 2 NWLR, Pt. $591,466-467$.

Ebeku, K. S. A., 'Constitutional Right to a Healthy Environment and Human Rights Approaches to Environmental Protection in Nigeria: Gbemre v. Shell Revisited' [2007] 16 (3) Review of European Community and International Environmental Law (RECIEL), 312-320.

Economic Commission for Africa (ECA), Review of the Application of Environmental Impact Assessment in Selected African Countries (ECA 2005), especially xvi, 46 and 73-74.

Egwemi V., Wuam T. and Orngu C. S. (eds), Federalism, Politics and Minorities in Nigeria Essays in Honour of Professor G. N. Hembe (Bahiti and Dalila Publishers 2014).

Enyoghasim M. O., Anochiwa L., Agbanike F. T., Uwazie I. U., Kalu E. U., Onwuka O. K., Okwor S. A., Ogbonnaya I. O., 'Oil Exploration and Exploitation in Nigeria and the Challenge of Sustainable Development: An Assessment of the Niger Delta' [2019] 9 (4) International Journal of Energy Economics and Policy, 369380 .

Eromosele V. E., Nigerian Petroleum Business: A Handbook (WIT Press 1997).

Etemire U., Law and Practice of Public Participation in Environmental Matters: The Nigerian Example in Transnational Corporative Perspective (Routledge 2016), 59-60.

Eweje G., Environmental Costs and Responsibilities from Oil Exploitation in Developing Countries: The Case of the Niger Delta of Nigeria' [2006] 69 (1) Journal of Business Ethics, 27-56.

Federal Environmental Protection Agency (FEPA), Environmental Impact Assessment Procedural Guidelines (FEPA 1995).

FEPA, Environmental Impact Assessment Sectoral Guidelines: Manufacturing Industries (FEPA 1995).

FEPA, National Policy on the Environment (FEPA 1999).

FEPA, Nigeria's National Agenda 21 (FEPA 1999).

FEPA, 'Sub-Sectoral Guidelines for Petroleum Refining' in Environmental Impact Assessment Sectoral Guidelines for Oil and Gas Industry Projects (FEPA 1995).

Federal Government of Nigeria, Draft Final Report E2283, captioned 'Infrastructure Concession and Regulatory Commission Environmental and Social Management Framework for Nigeria Public Private Partnership Program' (November 3, 2009), 50.

Federal Ministry of Environment (FMEnve), National Guidelines for Environmental Impact Assessment Act (Act 86. 1992): Mining (FMEnve 2013).

Filho W. L., Pociovalisteanu D. and Al-Amin A. Q.(eds), Sustainable Economic Development: Green Economy and Green Growth (Springer International Publishing 2017). 
Frynas J. G., Oil in Nigeria: Conflict and Litigation between Oil Companies and Village Communities (Transaction Publishers 1993).

Frynas J. G., 'The False Developmental Promise of Corporate Social Responsibility: Evidence from Multinational Oil Companies', [2005] 81 (3) International Affairs, 581-598.

Frynas J. G. and Pegg S. (eds), Transnational Corporations and Human Rights (Palgrave Macmillan 2003).

Gardiner S. M. and Thompson A. (eds), The Oxford Handbook of Environmental Ethics (Oxford University Press 2017).

Gary I. and Karl T. L., Bottom of the Barrel: Africa's Oil Boom and the Poor (Catholic Relief Services 2003).

Gbemre (Jonah Gbemre) $v$ The Shell Petroleum Development Company Nigeria Ltd \& 2 Ors [2005] $\mathrm{FHC} / \mathrm{B} / \mathrm{CS} / 53 / 05)$.

Gboyega A., Søreide T., Minh Le T. and G. P. Shukla G. P. (eds), 'Political Economy of the Petroleum Sector in Nigeria' [20112] WPS5779 Policy Research Working Paper 5779 of The World Bank Africa Region Public Sector Reform and Capacity Building Unit, 1-48.

Gilpin A., Environmental Impact Assessment (EIA): Cutting Edge for the Twenty-First Century (Cambridge University Press 1995), 2.

Gilpin A., Dictionary of Environmental Law (Edward Elgar Publishing 2000).

Ginther, K., Denters, E. and de Waart, P. J. I. M. (eds), Sustainable Development and Good Governance (Martinus Nijhoff Publishers 1995).

Habila H., Oil on Water (Penguin Books 2011).

Hannesson R., Investing for Sustainability: The Management of Mineral Wealth (Kluwer 2001).

Harding A. (ed), Access to Environmental Justice: A Comparative Study (Brill 2007).

Helios Towers Nig. Ltd v National Environmental Standards and Regulations Enforcement Agency (NESREA) \& Anor [2009/2010] Suit No. FHC/KD/CS/65/2009 and Appeal No. CA/K/123/2010.

Hemmati M., Multi-Stakeholder Processes for Governance and Sustainable Development: Beyond Deadlock and Conflict (Earthscan 2002).

Hill J., Nigeria Since Independence: Forever Fragile? (Palgrave Macmillan 2012).

Holdar G. G. and Zakharchenko O. (eds), Citizen Participation Handbook: People's Voice Project International Centre for Policy Studies (iMedia 2002).

Hynes W. and Wang S., Green Growth and Developing Countries: A Summary for Policy Makers (The Organisation for Economic Co-operation and Development [OECD] 2012).

International Institute for Environment and Development (IIED) and World Business Council for Sustainable Development (WBCSD), Breaking New Ground: Mining, Minerals, and Sustainable Development: The Report of the MMSD Project (Earthscan 2002).

Jackson T., Prosperity without Growth: Economics for a Finite Planet (Earthscan 2011).

Jackson T., Prosperity without Growth?: The Transition to a Sustainable Economy (Sustainable Development Commission 2009).

Karl T. L., The Paradox of Plenty: Oil Booms and Petro-States (University of California Press 1997).

Kelly W. E., Luke B. and Wright R. N., Engineering for Sustainable Communities Principles and Practices (American Society of Civil Engineers 2017).

Kiss C. and Ewing M. (eds), Environmental Democracy An Assessment of Access to Information, Participation in Decision-making and Access to Justice in Environmental Matters in Selected European Countries (The Access Initiative, Europe/Environmental Management and Law Association [EMLA])

Klare M., Blood and Oil (American Empire Project (Holt Paperbacks 2005).

Kwaghe Z. E., 'Black Gold and the Nigerian State (1956-2014): A Critical Review' [2015] 14 (2) Chinese Business Review, 72-86.

Lafferty W. M. and Eckerberg K. (eds), From Earth Summit to Local Agenda 21: Working towards Sustainable Development (Earthscan 1998).

Lange P., Sustainability Governance: Exploring the Potential of Governance Modes to Promote Sustainable Development (Sustainable Development in the $21^{\text {st }}$ Century) (Nemos Verlagsgesellschaft 2017).

Lucena J., Schneider J. and Leydens J. A., 'Engineering and Sustainable Community Development [2010] 5 (1) Synthesis Lectures on Engineers, Technology, and Society, 1-230.

Manby B., The Price of Oil: Corporate Responsibility and Human Rights Violations in Nigeria's Oil Producing Communities (Human Rights Watch 1999).

Mason M., Environmental Democracy: A Contextual Approach (Earthescan1999).

Mauerhofer V. (ed), Legal Aspects of Sustainable Development: Horizontal and Sectorial Policy Issues (Springer International Publishing Switzerland 2016).

McCabe M. and Sadler B. (eds), Environmental Impact Assessment Training Resource Manual, (The Economic and Trade Branch, Division of Technology, Industry and Economics (DTIE), UNEP, 2002).

McCabe M. and Sadler B. (eds), Studies in EIA Practice in Developing Countries (The Economic and Trade 
Branch, Division of Technology, DTIE, UNEP, 2002).

Meadowcroft J. and Lafferty W. (eds), Democracy and the Environment: Problems and Prospects (Edward Elgar Publishing 1998).

Morrison J., International Business Challenges in a Changing World (Springer Nature 2019).

Morrison J., The Social Licence: How to Keep Your Organization Legitimate (Palgrave Macmillan 2014).

Moser C. O. N., Community Participation in Urban Projects in the Third World (Progress in Planning S.) (Pergamon 1990).

Morrison R., Ecological Democracy (South End Press 1995).

Morrison-Saunders A. and Arts J. eds), Assessing Impact: Handbook of EIA and SEA Follow-up (Earthscan, 2006); Mulgan M., People and Participation: How to Put Citizens at the Heart of Decision-making (Involve 2005).

Nwadiaru R., Nigeria: A Failed State: Profound Treatise on a Crippled Giant (Tate Publishing 2012).

Obi C. and Rustad S. A. (eds), Oil and Insurgency in the Niger Delta: Managing the Complex Politics of Petroviolence (Zed Books 2011).

Okene O. V. C. (ed), Readings in Law and Policy (Current Issues and Trends): (In Commemoration of the Golden Jubilee of Rivers State (1967-2017) (Faculty of Law, Rivers State University 2017).

Oluwadare A. J. and Oyebode M. O., 'Oil Resource as a Major Source of Insecurity in the Niger Delta of Nigeria' [2013] 3 (21) Research on Humanities and Social Sciences, 32-44.

Omede A. J. and Bakare A. R., 'The Impact of Civil Society Organizations on Sustainable Development in Developing Countries: The Nigerian Experience' [2014] 8 (1) African Research Review, 205-227.

Omeje K. (ed), Extractive Economies and Conflicts in the Global South: Multi-Regional Perspectives on Rentier Politics (Ashgate Publishing 2008).

Omeje K., High Stakes and Stakeholders: Oil Conflict and Security in Nigeria (Routledge 2016).

Omeje K. (ed), State-Society Relations in Nigeria: Democratic Consolidation, Conflicts and Reforms (Adonis \& Abbey 2007).

Omorogbe Y. and Ordor A. O. (eds), Ending Africa's Energy Deficit and the Law: Achieving Sustainable Energy for All (Oxford University Press, 2018).

Onwuka E. C., 'Oil Extraction, Environmental Degradation and Poverty in the Niger Delta Region of Nigeria' [2005] 62 (6) International Journal of Environmental Studies, 655-662.

Peel D. and Bailey N. Celebrating Community Involvement (Development Trusts Association 2003), especially 315.

Perman R., Ma Y., Common M., Maddison D. and Mcgilvray J., Natural Resource and Environmental Economics (Addison Wesley/Pearson Education 2011).

Puppim de Oliveira J. A., (ed), Green Economy and Good Governance for Sustainable Development: Opportunities, Promises and Concerns (UN University Press 2012).

Ross H. and Marafono K., From SAS to Blood Diamond Wars (Pen \& Sword Military 2011).

Rousseau J., The Social Contract (Wordsworth Classics of World Literature) (Wordsworth Editions 1998).

Rousseau J., The Social Contract or Principles of Political Right (Aziloth Books 2011).

Russell R. and Rus V. (eds), International Handbook of Participation in Organizations: Ownership and Participation (Oxford University Press 1991).

Sachs J. F., The Age of Sustainable Development (University of Columbia Press 2015).

Sadler B., Aschemann R., Dusik T., Fischer T., Partidario M. and Verheem R. (eds), Handbook of Strategic Environmental Assessment (Earthscan, 2011).

Sidaway R., Resolving Environmental Disputes from Conflicts to Consensus (Earthscan 2013).

Stec S., Casey-Lefkowitz S. and Jendroska J., The Aarhus Convention: An Implementation Guide (UN 2000), v.

Stevens P. J., 'The Resource Curse Revisited Appendix: A Literature Review' [2015] The Royal Institute of International Affairs, 1-42.

Suberu R. T., Ethnic Minority Conflicts and Governance in Nigeria (Spectrum 2003).

Suberu R. T., Federalism and Ethnic Conflict in Nigeria (United States Institute of Peace 2001).

The Shell Petroleum Development Company Nigeria Limited (SPDC/Shell Nigeria), Environmental Impact Assessment (EIA) Process: Stakeholders' Guide (Document No. SPDC 2003-069, June 2003).

The Shell Petroleum Development Company Nigeria Limited (SPDC/Shell Nigeria), Accompanying Guidelines for SPDC EIA Process: Stakeholders Identification and Involvement (SPDC 2004-0002710, Vol. I, March 2004).

The Shell Petroleum Development Company Nigeria Limited (SPDC/Shell Nigeria), Accompanying Guidelines for SPDC EIA Process: Scoping (SPDC 2004-0002711, Vol. II, March 2004).

The Shell Petroleum Development Company Nigeria Limited (SPDC/Shell Nigeria), Accompanying Guidelines for SPDC EIA Process: Data Collection (SPDC 2004-0002712, Vol. III, March 2004).

The Shell Petroleum Development Company Nigeria Limited (SPDC/Shell Nigeria), Accompanying Guidelines for SPDC EIA Process: Report Review (SPDC 2004-0002713, Vol. IV, March 2004). 
The Shell Petroleum Development Company Nigeria Limited (SPDC/Shell Nigeria), Accompanying Guidelines for SPDC EIA Process: Preparation and Implementation of Environmental Management Plan (SPDC 20040002714, Vol. V, March, 2004).

Tamuno T., Oil Wars in the Niger Delta 1849-2009 (Stirling-Horden Publishers 2011).

Tan C. and Faundez J. (eds), Natural Resources and Sustainable Development: International Economic Law Perspectives (Edward Elgar Publishing 2017).

UN Association of Australia (UNAA), The Earth Charter (UNAA 2017).

UN Department on Economic and Social Affairs (UNDESA), Indicators of Sustainable Development: Guidelines and Methodologies (UN 2007).

UN Economic and Social Commission for Asia and the Pacific (UNESCAP), Public Involvement Guideline for Natural Resource Development Projects (UN 1997), 4-5.

UN Environment Programme (UNEP), Environmental Assessment of Ogoniland (UNEP 2011.

UNEP, Healthy Environment, Healthy People (UNEP 2016).

van der Ploeg F., 'Natural Resources: Curse Or Blessing?' [2011] 49 (2) Journal of Economic Literature, 366420.

Vanderheiden S. (ed), Environmental Rights: The International Library of Essays on Rights (Routledge 2016).

Venables A. J., 'Using Natural Resources for Development: Why Has It Proven So Difficult?' [2016] 30 (1) The Journal of Economic Perspectives, 161-183.

Venter Al J., Sierra Leone: Revolutionary United Front: Blood Diamonds, Child Soldiers and Cannibalism, 19912002 (History of Terror Series) (Pen \& Sword Military 2018).

Warburton D. (ed), Community and Sustainable Development: Participation in the Future (Routledge 2016).

Wilkinson A., Gollan P. J., Marchington M. and Lewin D. (eds), The Oxford Handbook of Participation in Organizations (Oxford University Press 2010).

Wilson E., 'What is Social Licence to Operate? Local Perceptions of Oil and Gas Projects in Russia's Komi Republic and Sakhalm Island' [2016] The Extractive Industries and Society, 3 (1) 73-81.

The World Bank Population and Human Resources Division Western Africa Department Africa Region, Nigeria Poverty in the Midst of Plenty The Challenge of Growth with Inclusion A World Bank Poverty Assessment (The World Bank 1996).

The International Bank for Reconstruction and Development (The World Bank), The World Bank Participation Sourcebook (The World Bank, 1996).

The World Commission on Environment and Development (WCED), Our Common Future (Oxford University Press 1987), $\mathrm{x}-23,40$ and 43.

Zillman D. N., Lucas, A. R. and Pring, G. (R.), (eds), Human Rights in Natural Resources Development: Public Participation in Sustainable Development of Mining and Energy Resources (Oxford University Press 2002) preview, 1-120 and 549-587. 